\title{
Prediction of Permanent Deformation of Foamed and Emulsified Sulfur Asphalt Soils Mixes
}

\author{
H.I. Al-Abdul Wahhab*, a and G.M.S. Abdullah \\ ${ }^{a}$ Department of Civil Engineering, King Fahd University of Petroleum and Minerals, Dhahran 31261, Saudi Arabia \\ ${ }^{b}$ Department of Civil Engineering, Najran University, Najran, Saudi Arabia
}

Received 24 November 2014; accepted 12 August 2015

\begin{abstract}
This paper presents a study carried out to evaluate and compare the permanent deformation of marginal soils. Under consideration were marl, sabkha and dune sand stabilized with foamed and emulsified sulfur asphalt (FSA, ESA) with mixes of the same soils stabilized with conventional foamed and emulsified asphalt (FA, EA) for road base construction. Designed mixes at their optimum asphalt content were evaluated for the dynamic resilient modulus $\left(\mathrm{M}_{\mathrm{R}}\right)$ at $22^{\circ} \mathrm{C}$ and $40^{\circ} \mathrm{C}$ and dynamic triaxial at three levels of deviatoric stress and at $22^{\circ} \mathrm{C}$ and $40^{\circ} \mathrm{C}$. The wheel tracking (WT) test was carried out at $22^{\circ} \mathrm{C}$. Permanent deformation of stabilized mixes with optimum binder contents was modeled and simulated using dynamic triaxial and WT tests. The developed models were calibrated to predict rutting using VESYS 5W software. Results indicated that the FSA increased rutting resistance as compared to conventional FA mixes. On the other hand, ESA increased the rutting susceptibility of marl soil as compared to EA. The calibrated models of rutting prediction were found to predict the rut depth with $90 \%$ accuracy.
\end{abstract}

Keywords: Rutting, Dynamic triaxial, Wheel tracking, Calibrated models, VESYS.

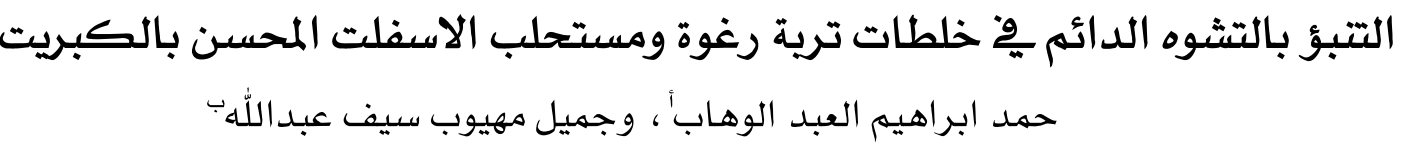

الملخص: عرضت هذه الورقة دراسة تم إجراؤها للتتبؤ وتقييم التشوه الدائم (التخدد) الناتج وِ التربة الهامشية الضعيفة مثل التربة الجيرية (المارل) والسبخة والكثبان الرملية المعالجة برغوة ومستحلب الاسفلت المحسن بالكبريت ومقارنتها مع خلطات من نفس التربة المعالجة برغوة ومستحلب الاسفلت التقليدية، وذلك بغرض إستخدامها ِِّ إنشاء قواعد اساس الطرق. تم تقييم الخلطات المصممة عند المحتوي الاسفلتي الامثل بإجراء إختبار معامل المرونة الديناميكي على اثنين من درجات الحرارة المختلفة (ب و •عْ م)، واختبار التحميل الديناميكي الثلاثي باستخدام ثلاث مستويات مختلفة من

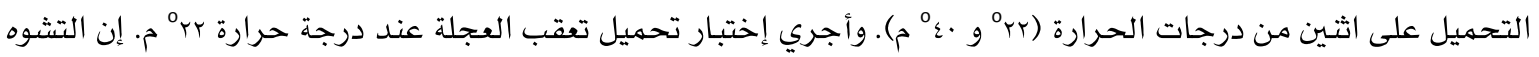
الدائم هُ الخلطات الاسفلتية المحتوية على المادة اللاصقة المثلى تم نمذجته ومحاكاته بإستخدام اختبارات التحميل الديناميكي الثلاثي وتعقب العجلة. وتمت معايرة هذة النماذج المشيدة لتتبؤ التخدد بإستخدام برنامج خاص (VESYS 5W). أشارت النتائج إلى أن رغوة الأسفلت المحسن بالكبريت زادت من مقاومة التخدد مقارنة مع خلطات رغوة الاسفلت التقليدية. ولكن من ناحية أخرى، أدى إستخدام مستحلب الاسفلت المحسن بالكبريت إلى زيادة التخدد للتربة الجيرية (المارل) مقارنة بخلطات مستحلب الاسفلت التقليدية. كما اشارت نماذج معايرة تتبؤ التخدد على أنها قادرة على التبؤ بعمق التخدد مع دقة تصل الى.9.

الكلمات المفتاحية: التشوه الدائم (التخدد) ، التحميل الديناميكي الثلاثي، تحميل تعقب العجلة ، نماذج المعايرة.

* Corresponding author's e-mail: hawahab@kfupm.edu.sa 


\section{Introduction}

A major stressor in flexible pavement is rutting, as indicated by the permanent deformation, or rut depth, sometimes found along wheel paths. Rutting in flexible pavement usually consists of longitudinal depressions in the wheel path due to the accumulation of small amounts of unrecoverable deformation caused by each load application (Fig. 1) (Hafeez and Imran H 2009; Asphalt Institute 1996). Many factors affect the width and depth of the rut, such as structural characteristics of pavement layers (thickness and material quality), traffic loads and environmental conditions. The accumulation of load-induced permanent deformation developed from all individual pavement layers, including the subgrade forms of surface rutting. A large percentage of the total rutting will mostly come from the under layers of pavement such as the base, subbase, and subgrade when the surface layer is thin.

Several models have been developed to predict rutting in asphalt concrete (AC) pavement layers and were evaluated in National Cooperative Highway Research Program (NCHRP) publication 1-26 (Barenberg et al. 1990). The study reported that those models which are related to the log of permanent strain to the log of load repetition appear to be the most suitable and versatile for practical use. This power model is often fitted to the accumulated permanent deformation curve and is definitely the most commonly used permanent deformation formula. The power model usually plots a straight line on a log-log scale. The slope and intercept of the power model, when plotted on a log-log scale, are used as indicators of permanent deformation resistance (Garba 2002).

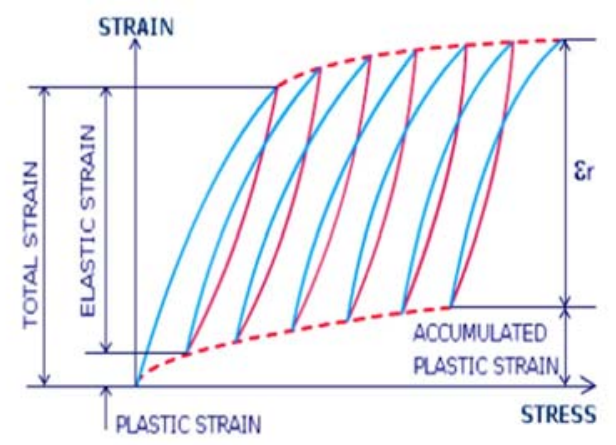

Figure 1. Accumulated Plastic Strains in Pavements (Asphalt Institute 1996).
The basic permanent strain to load repetition model is expressed as:

$\varepsilon_{\mathrm{p}}=\mathrm{aNb}$

This model was initially suggested for subgrade and unbound materials by Monismith, Carl LM (1976) and was first used for AC mixes by Khedr, Safwan AK (1986). Various researchers consequently used the same model for AC (Diyaljee and Raymond 1982; Vuong and Peter 1991; Gholam and William 1996), where $a$ and b are the intercept and slope coefficients and $\mathrm{N}$ is the load repetition. Figure 2 presents graphically the curve of a power model on a log-log scale between load repetition and permanent strain.

The progress of rutting with load repetition can be measured using layer elastic and viscoelastic theory. In order to get the cumulated permanent strain in each layer, the following equation is used (Hafeez, Imran H 2009):

$\varepsilon_{p}=\frac{\varepsilon \mu}{1-\alpha}(N)^{1-\alpha}$

where

$\mu=\frac{a b}{\varepsilon_{r}}=\mathrm{a}=1-\mathrm{b}$

$\varepsilon_{\mathrm{p}}=$ permanent strain (rut value)

$\mathrm{N}=$ number of load application

$\mathrm{a}=$ intercept coefficient of accumulated permanent strain versus number of load repetitions curve on log-log scale;

$\mathrm{b}=$ slope coefficient of accumulated permanent strain versus number of load repetitions curve on $\log -\log$ scale; and $\varepsilon_{\mathrm{r}}=$ resilient strain

$\varepsilon_{\mathrm{r}}=$ resilient strain

$\mu=$ ratio of plastic to elastic response

$\alpha=$ rate of change of the plastic response.

Thus, the total rut depth can now be calculated as:

$$
R_{D}=\sum_{i=1}^{n}=1\left(\varepsilon_{p i} \times h_{i}\right)
$$

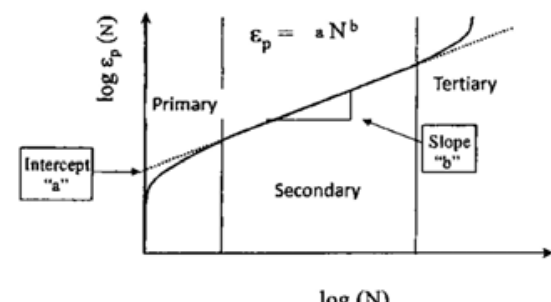

Figure 2. Log-log form of power model. 
where, $\mathrm{h}_{\mathrm{i}}$ is thickness of the layer.

According to Bevan (2002), a and $\mu$ are the stress- and temperature-dependent nonlinear parameters and can be used for modeling permanent deformation of mixes.

Thus, in order to predict the total permanent deformation of a pavement structure, one has to determine the properties of material in each layer and predict the layer rut. The VESYS model was adopted in this study since it is considered suitable to predict the layer and total rut depths of the pavement structure. The model parameters depend on the results of the experimental work on the material for each layer. Therefore, the dynamic triaxial repeated load test, which is a suitable lab test to obtain the VESYS model parameters, was conducted on the investigated materials.

\section{Experimental Work}

Marginal soils cover most of the eastern provinces of Saudi Arabia. In order to investigate the possible treatment of the marginal soils to be used in road construction, dune sand, marl, and sabkha soils were collected, subjected to basic characterization, and then stored for use in the experiments. The basic engineering properties of the soils were assessed by conducting preliminary characterization tests, including specific gravity, plasticity tests, and grain size distribution.

Standard foamed asphalt (FA) and 30/70 foamed sulfur asphalt (FSA) were produced using a calibrated laboratory scale FA plant WLB 10. The laboratory mix design procedure was carried out as outlined in the Wirtgen Cold Recycling Manual to determine the optimum asphalt content for the marl, sabkha, and dune sand soil mixes. After adding FA, 2\% cement was added to all mixes to prevent effecting the optimum moisture content (Wahhab et al. 2012). A set of test specimens $63.5 \pm 6$ $\mathrm{mm}$ high and $101.6 \mathrm{~mm}$ in diameter were prepared over a range of residual asphalt content. Mixes were designed using soaked indirect tensile strength (ITS) test. A relationship between soaked ITS and residual asphalt content was plotted and the optimum residual asphalt content, which provides the maximum soaked ITS, was determined.

For emulsified soils mixes, a set of test specimens $(63.5 \pm 6 \mathrm{~mm}$ high and $101.6 \mathrm{~mm}$ in diameter) were prepared over a range of residual asphalt contents.
Test mixtures were prepared in various increments of residual asphalt contents using previously determined amounts of premix water and the optimum water content required for mixing and compaction. Prepared mixtures were compacted in a Marshall mold with 75 blows for each side. After that, the molds containing the compacted specimens were placed on a perforated shelf in a $60^{\circ} \mathrm{C}\left(140^{\circ} \mathrm{F}\right)$ forced draft oven for 48 hours (Asphalt Emulsion Manufacturers Association, 2004). Specimens were soaked under $50 \mathrm{~mm} \mathrm{Hg}$ of vacuum pressure in water for one hour and without vacuum pressure for another hour and then tested for soaked stability. Based on the results, a relationship between soaked stability and residual asphalt content was plotted, and the optimum residual asphalt content providing the maximum soaked stability was determined.

Designed FSA and ESA at their optimum binder contents including marl, sabkha, and dune sand in addition to the mixes of these soils with conventional FA and EA were subjected to $M_{R}$ (AASHTO T-307), dynamic triaxial and wheel tracking (WT) tests to evaluate their permanent deformation behavior.

\section{Results}

The basic properties of the marginal soils (marl, sabkha and dune sand) used in this study were determined and the soils were classified. Stabilized soils treated with FSA and ESA, as well as the conventional FA and EA were designed utilizing indirect tensile strength (ITS) and Marshall stability. Optimum asphalt contents for all mixes are summarized in Table 1. The designed mixes at their optimum asphalt content were subjected to $\mathrm{M}_{\mathrm{R}}$ and dynamic triaxial (creep) at $22^{\circ} \mathrm{C}$ and $40^{\circ} \mathrm{C}$, representing relevant temperatures that base layers are subjected to in the summer and winter and wheel racking tests at $22^{\circ} \mathrm{C}$.

\subsection{Basic Soils Properties}

The dry and wet grain size distribution curves for marl, sabkha, and dune sand soils are shown in Fig. 3. Wet sieving of the sabkha was done with sabkha brine rather than distilled water in order to simulate field conditions. The investigated soils were non-plastic, based on Atterberg limit tests. The specific gravity values of the marl, sabkha, and dune sand soils were $2.69,2.71$ and $2.63 \mathrm{~kg} / \mathrm{m}^{3}$, respectively. 
Table 1. Optimum asphalt contents of soils mixes.

\begin{tabular}{ccc}
\hline Soil Type & Additive Type & Optimum Asphalt (\%) \\
\hline \multirow{3}{*}{ Marl } & FA & 9 \\
& FSA & 9 \\
& EA & 8.1 \\
& ESA & 7.2 \\
Sabkha & FA & 8 \\
& FSA & 7 \\
& EA & 4 \\
Sand & ESA & 3.6 \\
& FA & 7 \\
& FSA & 8 \\
& EA & 5.4 \\
\hline
\end{tabular}

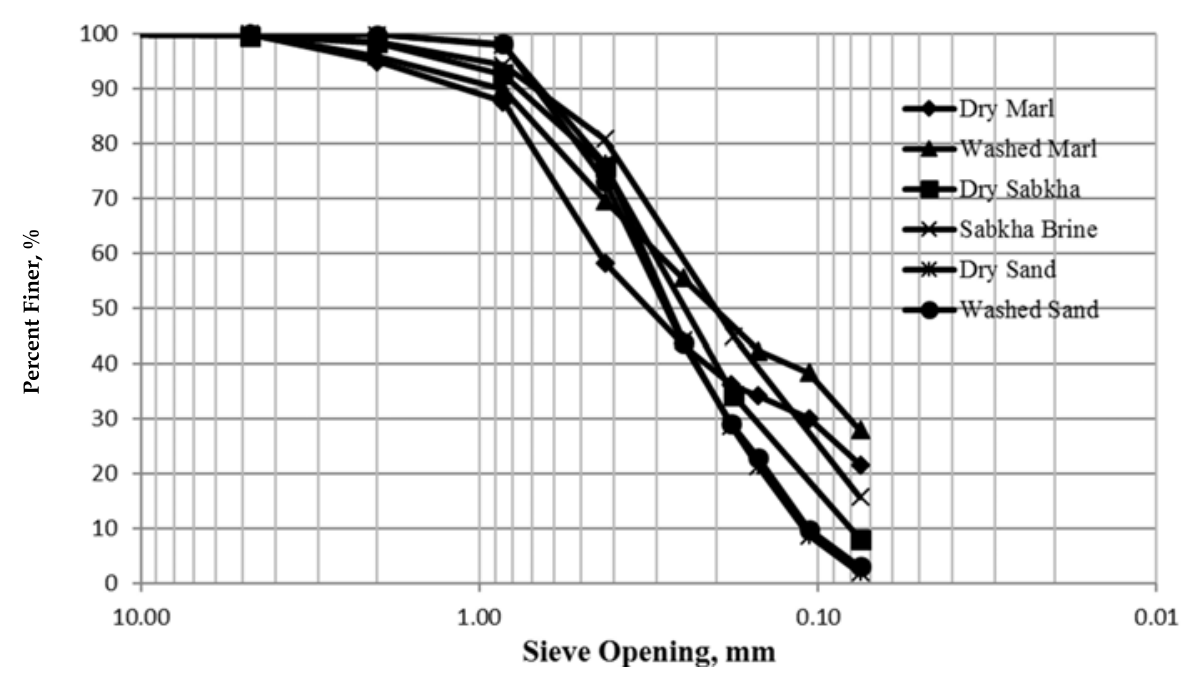

Figure 3. Grain size distribution of soils.

Marl and sabkha soils were classified as SM and A3 according to the Unified Soil Classification System (USCS) and American Association of State Highway and Transportation Officials (AASHTO) soil systems, respectively, based on both dry and wet sieving methods. However, dune sand was classified as SP and A-3 based on both dry and wet sieving methods.

It is clear from dry and wet sieve analysis curves for marl and sabkha soils that the wet sieving curve is always above that of the dry curve. This is ascribed to the fact that water tends to dissolve the salts between particles of the soil; thus, the proportion of wet materials passing through a particular sieve is consistently more than that for dry sieving. This difference would be higher if sabkha was sieved with distilled water instead of sabkha brine.

However, in sand soil, it can be seen that there is almost no variation between grain size distributions calculated by both the dry and wet sieving methods. This is ascribed to the fact that sand is made up of quartz which is not very affected by washing. 


\subsection{Resilient Modulus $\left(M_{R}\right)$}

A dynamic triaxial test was conducted at $22^{\circ} \mathrm{C}$ and $40^{\circ} \mathrm{C}$ to measure the dynamic $\mathrm{M}_{\mathrm{R}}$ at these two temperatures for marl, sabkha, and sand mixed with FA, FSA, EA and ESA. The dynamic $M_{R}$ was measured according to the AASHTO T-307 procedure. The specimens were tested under different combinations of confined pressure measuring 21-138 $\mathrm{kPa}$ (3-20 psi) and deviatoric stress measuring $34-276 \mathrm{kPa}(5-40 \mathrm{psi})$ to simulate the traffic loading that the granular base and subbase materials are subjected to in the road structures.

The variations of the $M_{R}$ with the deviator stress for all FA/FSA mixes at $22^{\circ} \mathrm{C}$ are presented in Fig. 4. The results indicate that there is a significant effect of the deviator stress variation on $M_{R}$ for all mixes. The $M_{R}$ increased greatly with the increase in the deviator stress. These findings are consistent with the results reported by Li and Liu (2010). Furthermore, the marl soil mixed with FA or FSA has the highest $M_{R}$ values, followed by sabkha and sand mixes. However, FSA mixes have lower $M_{R}$ values than the FA mixes.

Similarly, FA and FSA mixes were tested for the $M_{R}$ at $40^{\circ} \mathrm{C}$. The relationships between the $M_{R}$ and the deviator stress are presented in Fig. 5, which shows that, upon testing at $40^{\circ} \mathrm{C}$, the $\mathrm{M}_{R}$ values dropped by a magnitude of about $30 \%$ for FA mixes and $5-10 \%$ for FSA mixes, which is insignificant. The slight reduction in the $M_{R}$ of FSA mixes under an increased temperature as compared to FA may be attributed to the stiff bond between soil particles of the mix, which is improved due to the small-dispersed stiff droplets of FSA as a result of the foaming and mixing processes. At low ambient temperature, stiffness increases at the points where mineral particles are bounded by sulfur asphalt droplets while, where there were no sulfur asphalt droplets, the connection between particles did not change ( $\mathrm{Li}$ and Liu 2010). Thus, when temperatures increase, only the sulfur asphalt-bounded particles are affected, which are fewer in comparison to the mineral particles that are not bounded by sulfur asphalt droplets.

Furthermore, sulfur asphalt has a higher stiffness and less susceptibility to temperature differences as compared to plain asphalt, resulting in a stiffer mixes, which might justify its lower sensitivity to temperature variation.

The variations of $M_{R}$ with the deviator stress at $22^{\circ} \mathrm{C}$ for emulsified soils mixes are presented in Fig. 6, which clearly shows that the $M_{R}$ increased greatly with an increase in deviator stress. Additionally, the marl soil treated with EA or ESA has the highest $M_{R}$, followed by the sabkha and lastly by the sand soils treated with the same stabilizers. The difference, however, is insignificant. Figure 7 presents the variation of the $M_{R}$, measured at $40^{\circ} \mathrm{C}$, for the same soils mixed with EA and ESA. Again, there is a significant effect of deviator stress on the $M_{R}$ results. The $M_{R}$ increased significantly with the increase in the applied deviator stress; this is the same trend noticed for the $M_{R}$ measured at $22^{\circ} \mathrm{C}$. The results also show that there is a drop in the $\mathrm{M}_{\mathrm{R}}$ values measured at $40^{\circ} \mathrm{C}$ compared to those measured at $22^{\circ} \mathrm{C}$. This reduction in the $\mathrm{M}_{R}$ values appeared to be small in the ESA mixes compared to the EA mixes. Thus, the sulfur modified EA mixes are less sensitive to the temperature effect which is a great advantage.

In comparison, between the $\mathrm{M}_{\mathrm{R}}$ for the EA and ESA mixes, the moduli for the marl-ESA and sabkha-ESA are slightly higher than those for the marl-EA and sabkha-EA mixes, whereas the inverse is true for the sand soil.

\subsection{Dynamic Triaxial (Creep)}

A dynamic triaxial repeated load test was conducted on specimens $100 \mathrm{~mm}$ in diameter by $200 \mathrm{~mm}$ in height prepared at the optimum water and FA, FSA, EA and ESA contents and compacted to the maximum dry density. The specimens were tested under $10 \mathrm{psi}(68.95 \mathrm{kPa})$ of confining pressure and a $40-80$ psi range of deviator stress $(276-552 \mathrm{kPa})$ to simulate the traffic loading that the granular base and subbase materials are subjected to in the roads. The deviatoric stress was applied in the form of a sinusoidal (haversine) wave pulse with a loading time of 0.1 second followed by a reset period of 0.9 seconds. Repeated load tests were applied for treated mixes samples at lab temperatures of $22^{\circ} \mathrm{C}$ and $40^{\circ} \mathrm{C}$ and with deviator stress levels of 60,70 , and 80 psi $(414,483$, and $552 \mathrm{kPa}$ ) for stiff materials and 40,50, and 60 psi $(276,345$, and $414 \mathrm{kPa})$ for less stiff materials.

The results of the dynamic triaxial tests for the marl, sabkha and dune sand soils treated at the optimum percentages with FA and FSA and tested at $22^{\circ} \mathrm{C}$ are presented below (Figs. 8-10). It is clear that the marl soil has a high resistance to rutting, followed by sabkha and sand soils. Furthermore, the FSA mixes, except sand soil, reflect high rutting resistance in comparison to the FA mixes, which is considered a great advantage for newly investigated FSA.

However, for the sand soil, the difference is not as high, and the permanent deformation is high either for the standard FA mixes or the modified FSA mixes. 


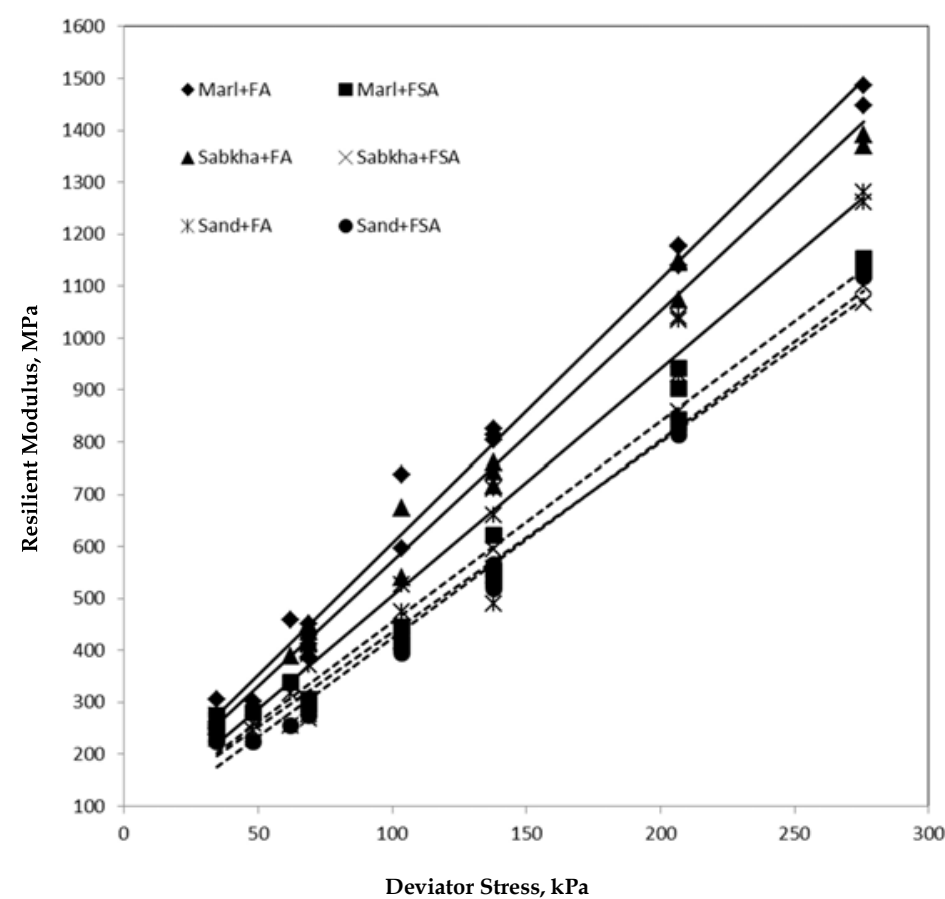

Figure 4. Variation of $\mathrm{M}_{\mathrm{R}}$ with deviator stress for the foamed soils at $22^{\circ} \mathrm{C}$.

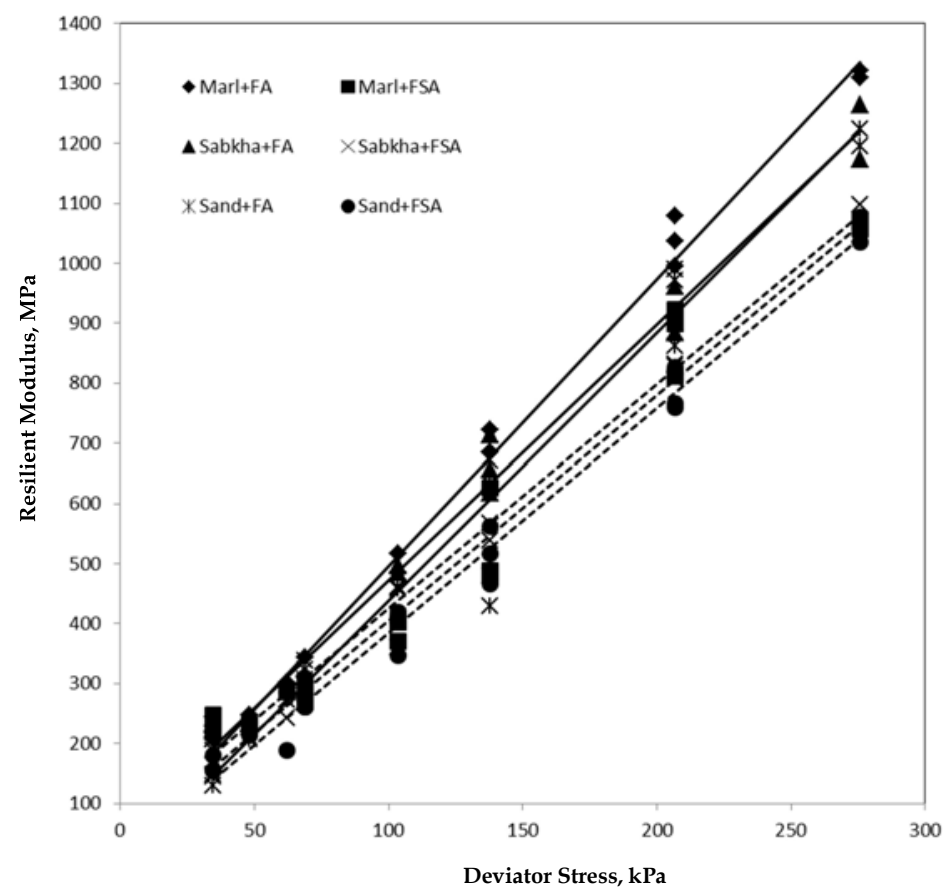

Figure 5. Variation of $\mathrm{M}_{\mathrm{R}}$ with deviator stress for foamed soils at $40^{\circ} \mathrm{C}$. 


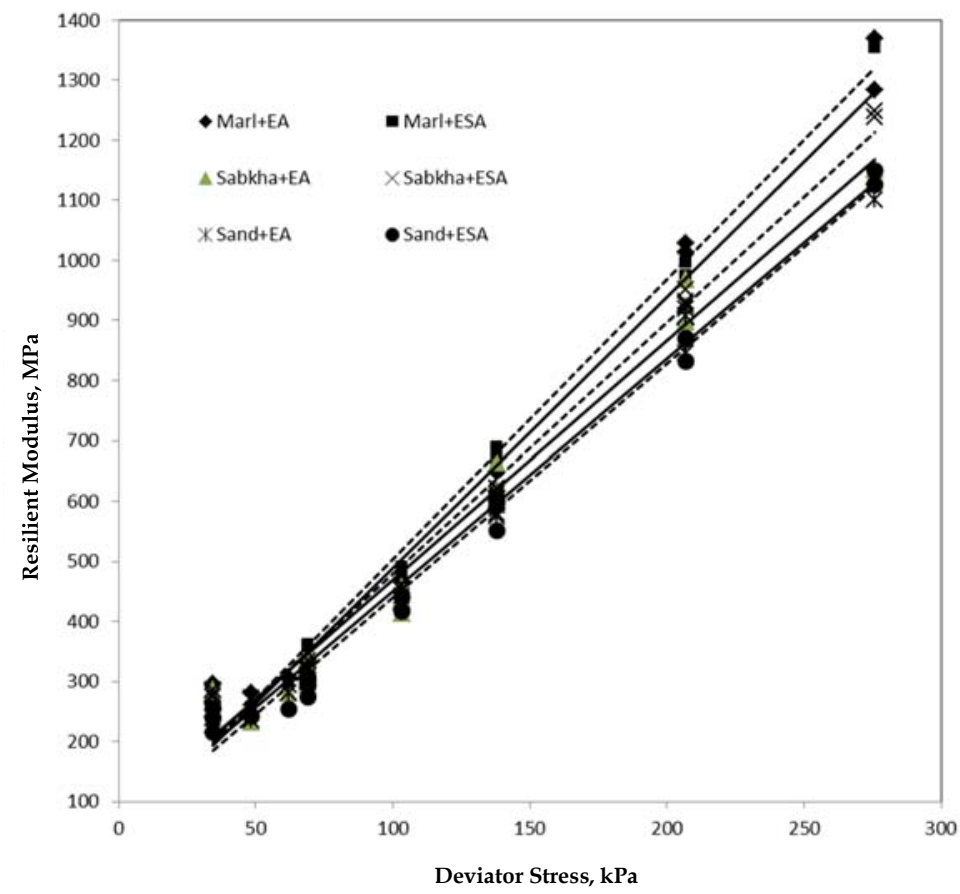

Figure 6. Variation of $\mathrm{M}_{\mathrm{R}}$ with deviator stress for emulsified soils at $22^{\circ} \mathrm{C}$.

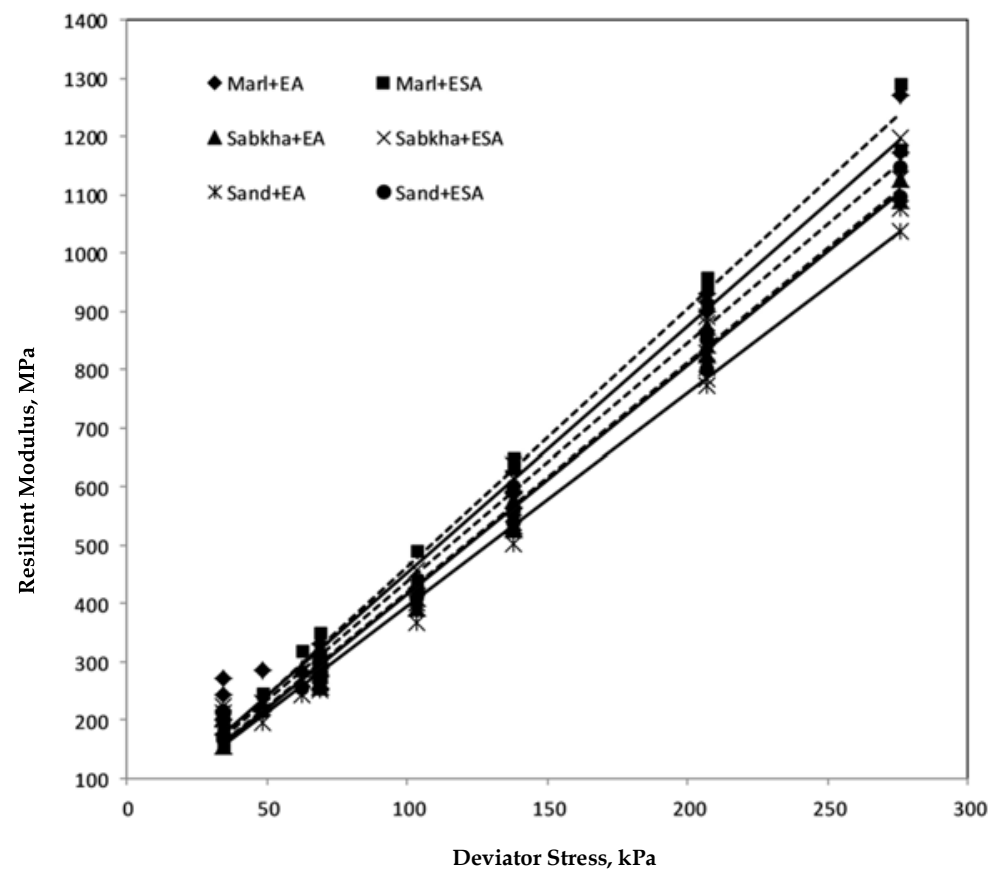

Figure 7. Variation of $\mathrm{M}_{\mathrm{R}}$ with deviator stress for emulsified soils at $40^{\circ} \mathrm{C}$. 


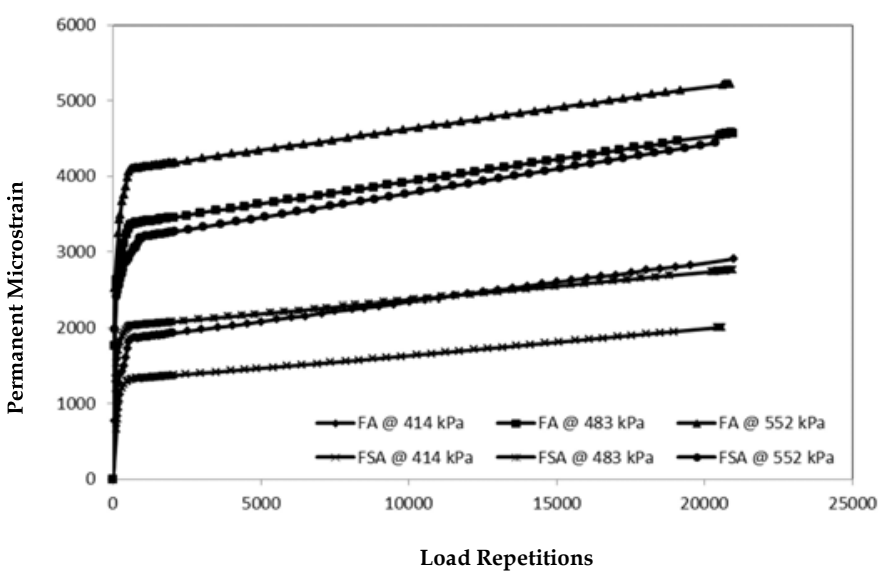

Figure 8. Dynamic triaxial test results for marl-FA/FSA at $22^{\circ} \mathrm{C}$.

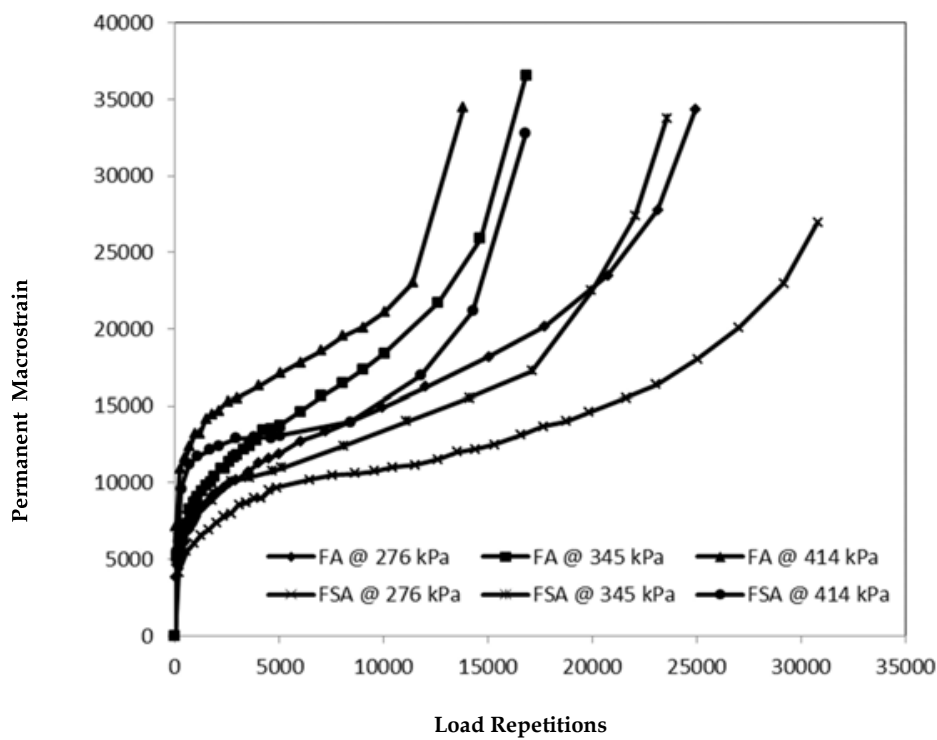

Figure 9. Dynamic triaxial test results for sabkha-FA/FSA at $22^{\circ} \mathrm{C}$.

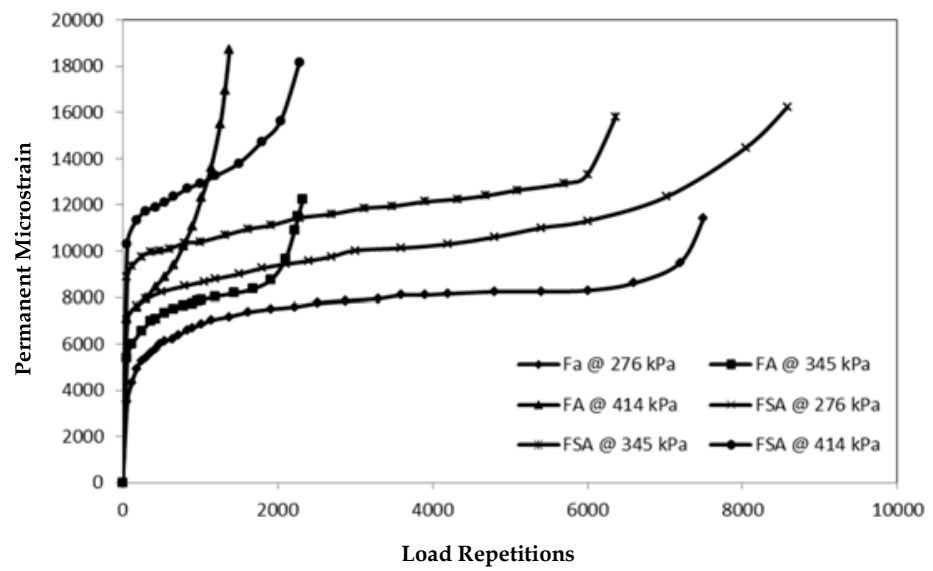

Figure 10. Dynamic triaxial test results for sand-FA/FSA at $22^{\circ} \mathrm{C}$. 
The increase in the resistivity of the sulfur modified mixes to the permanent deformation may be ascribed to the increased asphalt stiffness. Similarly, Figs. 11-14 show the results of the dynamic triaxial test for the same soils tested at $40^{\circ} \mathrm{C}$. The same trend as was found at $22^{\circ} \mathrm{C}$ is noticeable for the sabkha soil and marl, in which
FSA mixes have higher resistance to permanent deformation. In addition to that and based on the results of the dune sand mixes shown in Figs. 13 and 14, in spite of the weakness of the sand mixes, the FSA mix is more resistant to permanent deformation than the FA mix when tested at $40^{\circ} \mathrm{C}$, particularly under low to medium loading stresses.

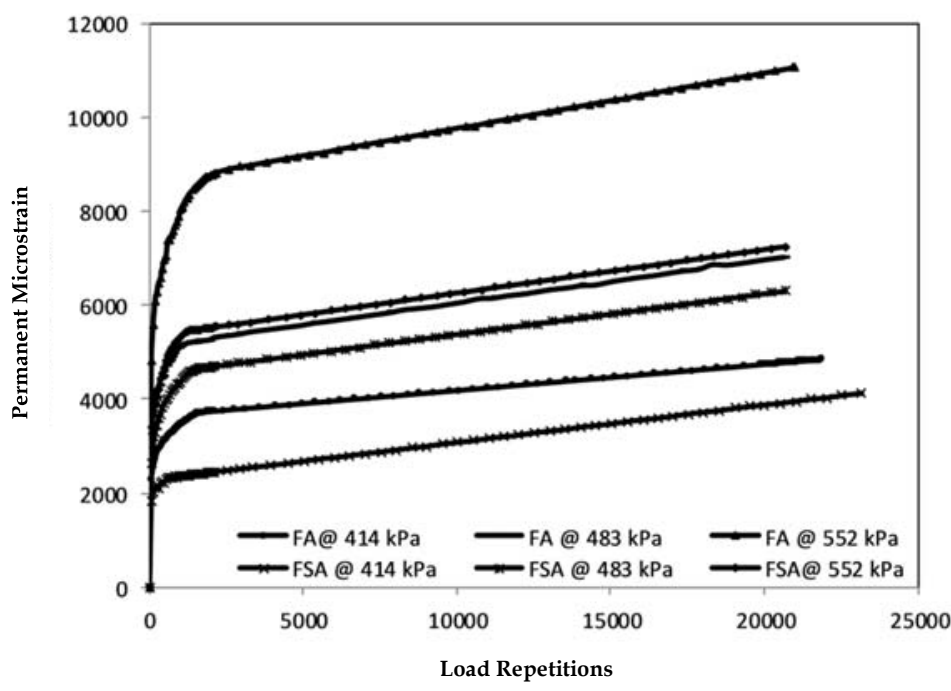

Figure 11. Dynamic triaxial test results for marl-FA/FSA at $40^{\circ} \mathrm{C}$.

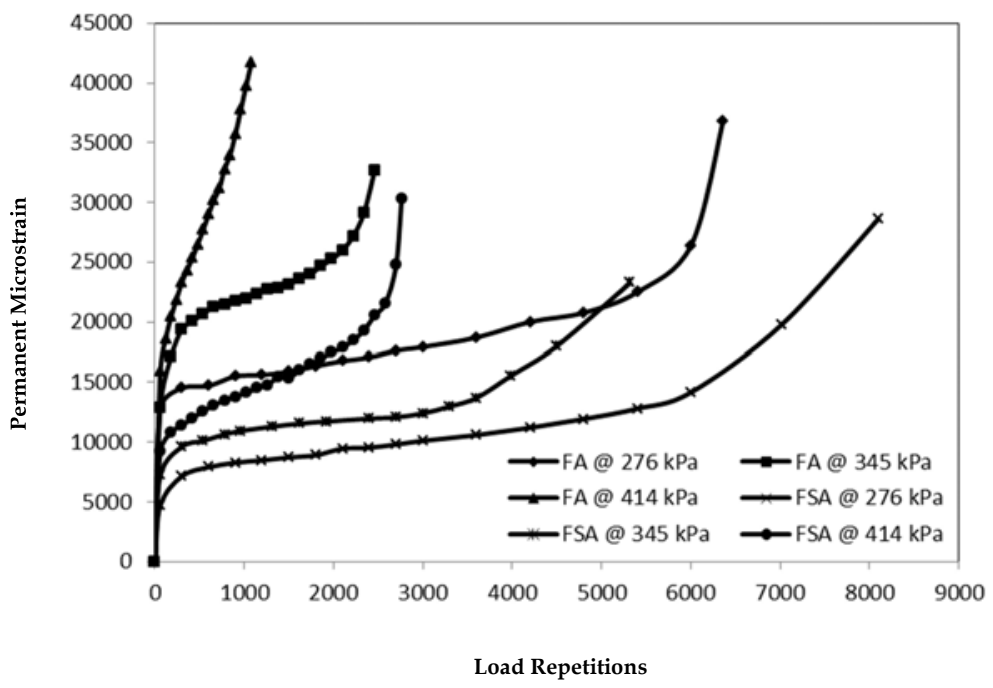

Figure 12. Dynamic triaxial test results for sabkha-FA/FSA at $40^{\circ} \mathrm{C}$. 


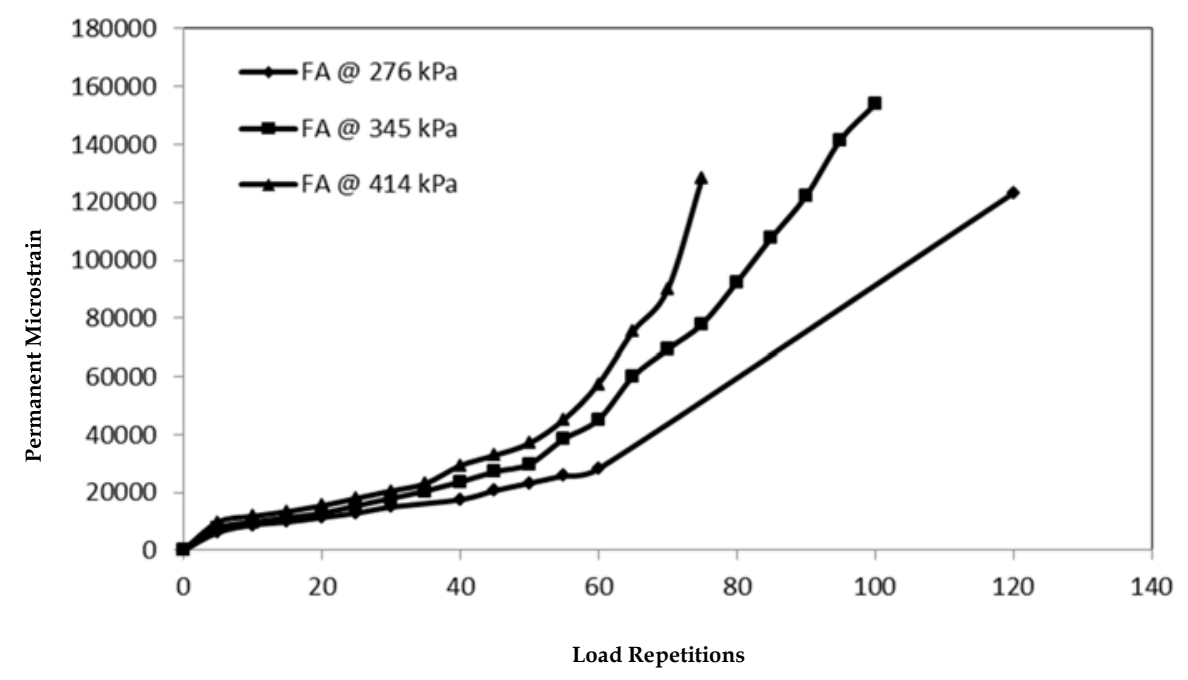

Figure 13. Dynamic triaxial test results for sand-FA at $40^{\circ} \mathrm{C}$.

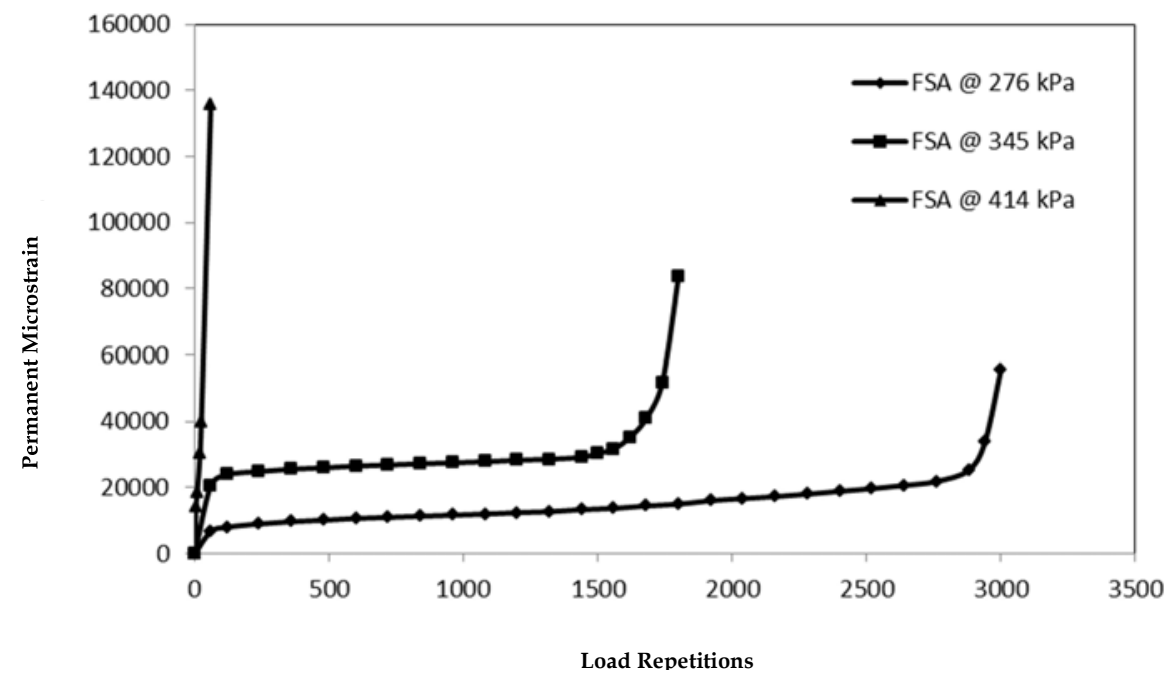

Figure 14. Dynamic triaxial test results for sand-FSA at $40^{\circ} \mathrm{C}$.

Figures 15-17 show the results of the dynamic triaxial tests of EA and ESA mixes conducted at $22^{\circ} \mathrm{C}$. Contrary to the foamed mixes, the addition of the modified ESA to the soils increased the possibility of rutting, especially for marl and sand soils. Sabkha soil ESA mixes showed less permanent deformation than the EA mixes, but they reached to the failure stage earlier than EA mixes, particularly at high stress levels. Such behavior may be attributed to the reduction in the shear strength parameters ( $C$ and $\phi)$ of the soils when treated with ESA rather than conventional EA. It should be noted that the internal friction angle of traded soils did not change significantly due to the treatment type while the cohesion has dropped considerably when ESA was used instead of EA.

Figures 18-20 show the dynamic triaxial test results for the same three soils tested at $40^{\circ} \mathrm{C}$. Based on the results for the marl soil, the same trend found when testing at $22^{\circ} \mathrm{C}$ is clearly present [Fig. 18]. Here, the mixes remained in the second stage of the creep curve and did not reach to the failure stage as happened when testing at $22^{\circ} \mathrm{C}$ and under $80 \mathrm{psi}(552 \mathrm{kPa})$ of loading, which means that sulfur mixes perform well at higher temperatures.

On the other hand, sabkha and sand soils show the inverse trend. ESA mixes are less sensitive to rutting in comparison to conventional mixes which were found to fail rapidly (Figs. 19-20). 
Furthermore, the mixes did not reach the failure stage, particularly at low to medium loading for sand and for all levels of loading in the case of the sabkha soil. In addition, the slope (b) and intercept (a) of the permanent deformation curves are low which leads to a high $\alpha$ and low $\mu$ for rutting model parameters, resulting in low rutting prediction. Hence, the sulfur modified emulsion mixes have lower temperature susceptibility than conventional mixes.

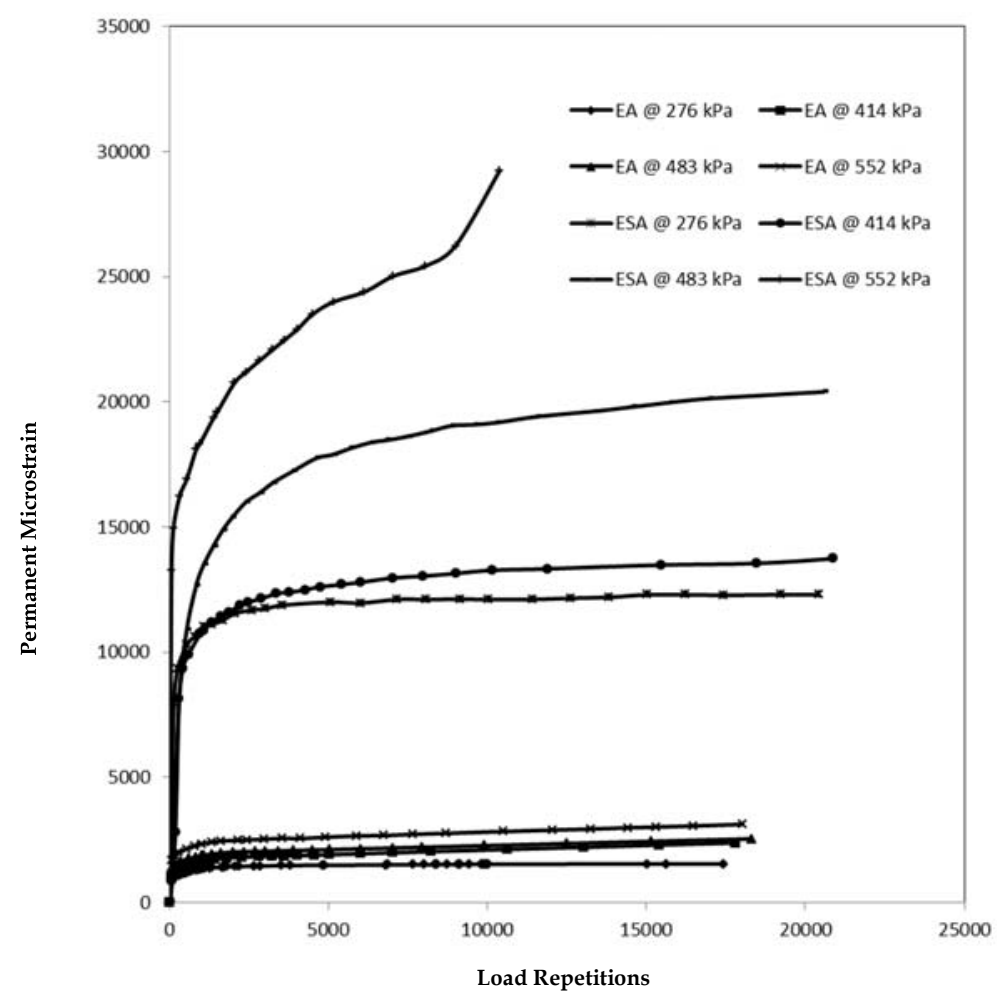

Figure 15. Dynamic triaxial test results for marl-EA/ESA at $22^{\circ} \mathrm{C}$.

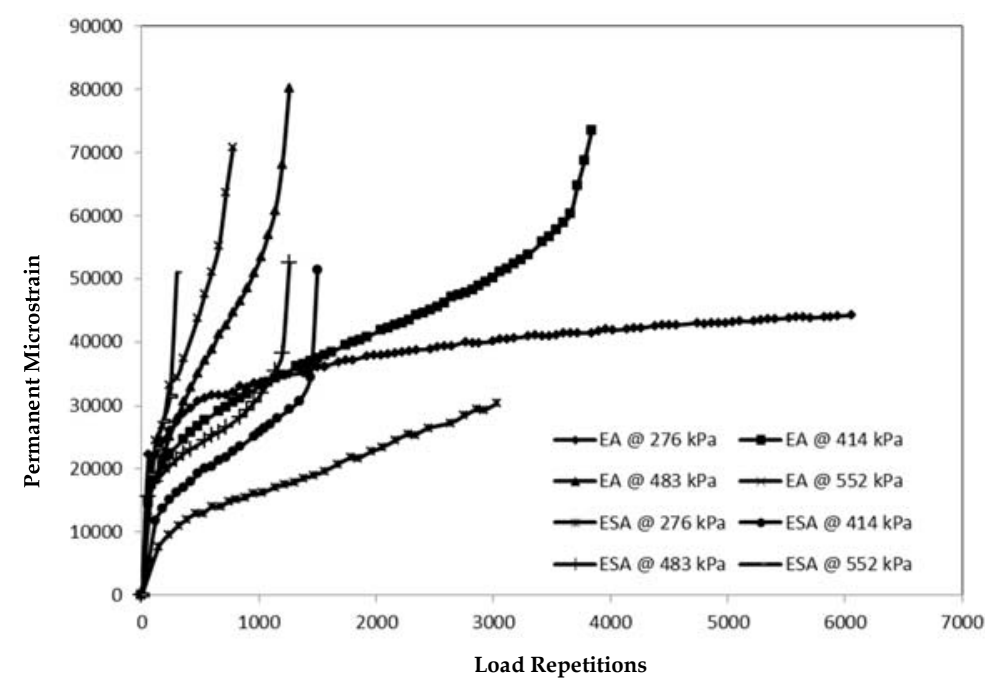

Figure 16. Dynamic triaxial test results for sabkha-EA/ESA at $22^{\circ} \mathrm{C}$. 


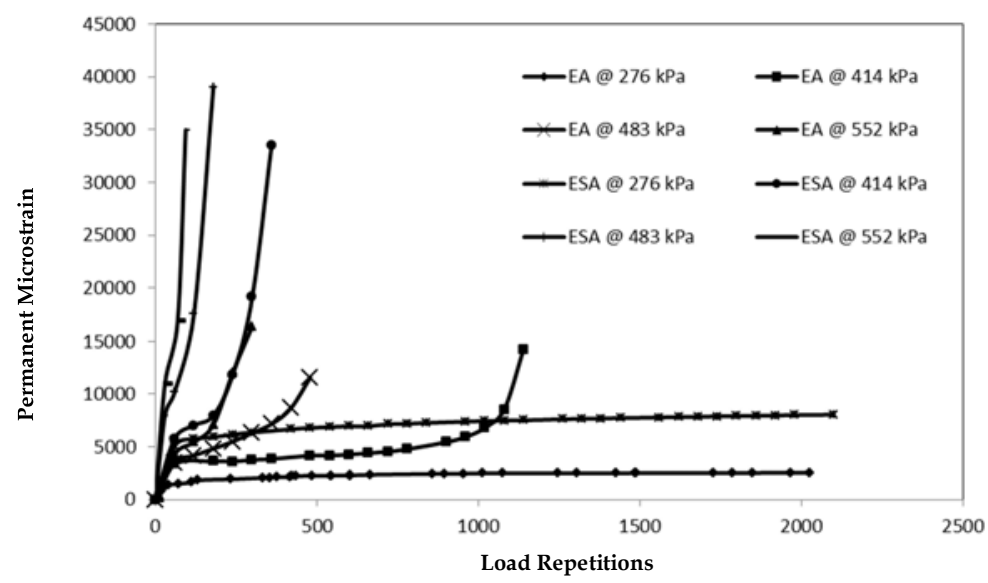

Figure 17. Dynamic triaxial test results for sand-EA/ESA at $22^{\circ} \mathrm{C}$.

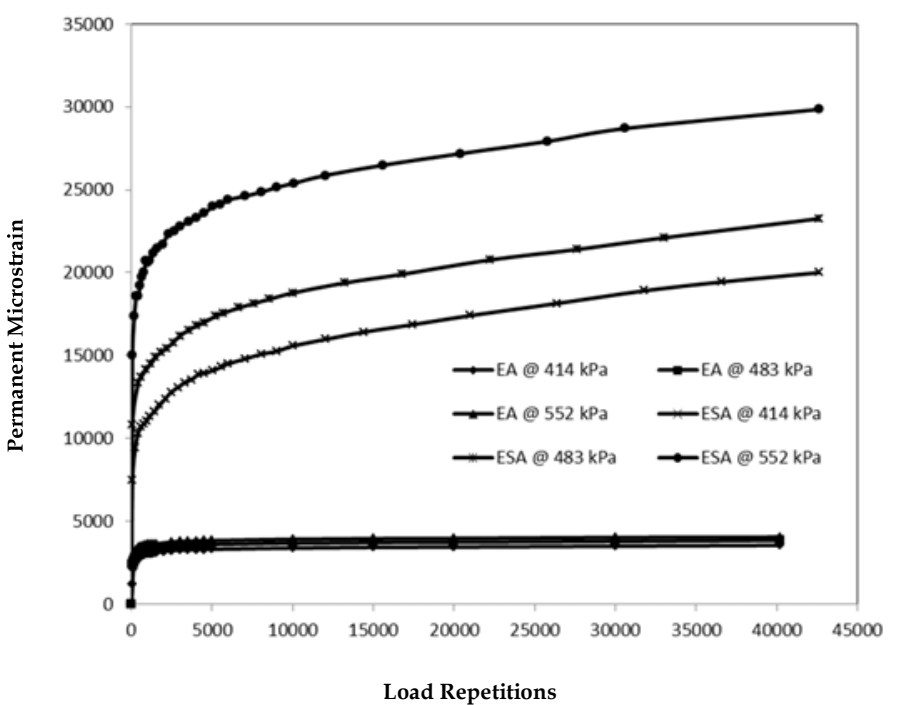

Figure 18. Dynamic triaxial test results for marl-EA/ESA at $40^{\circ} \mathrm{C}$.

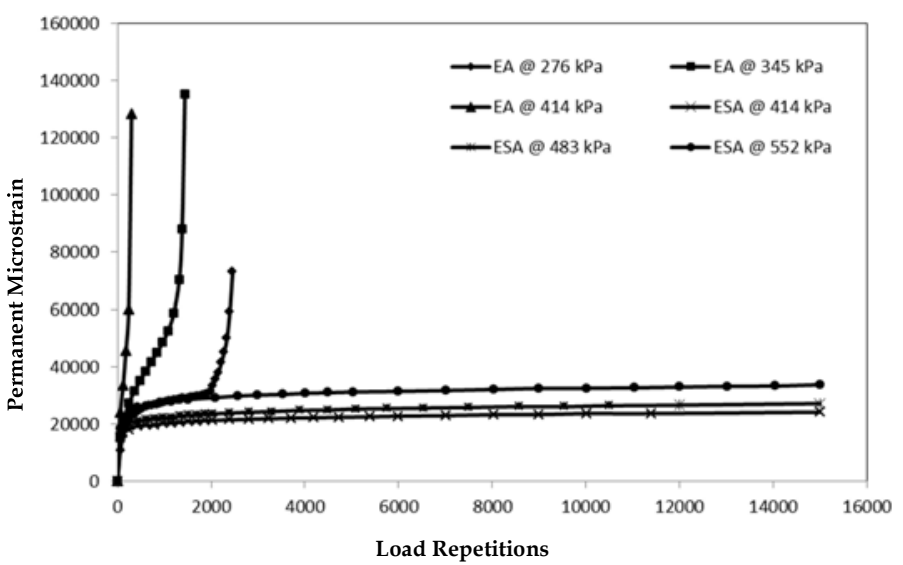

Figure 19. Dynamic triaxial test results for sabkha-EA/ESA at $40^{\circ} \mathrm{C}$. 


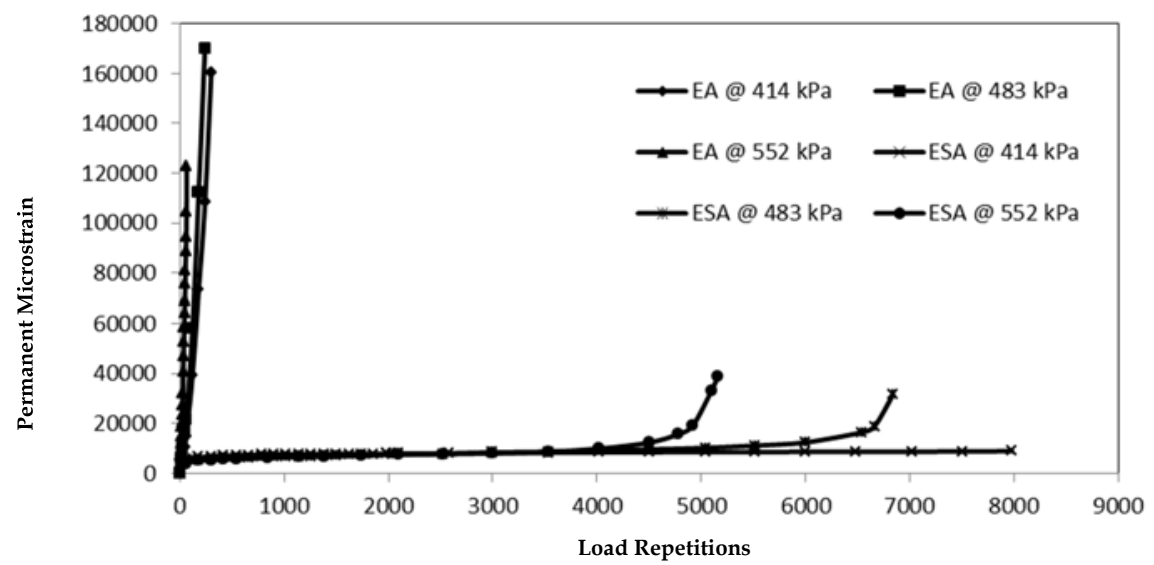

Figure 20. Dynamic triaxial test results for sand-EA/ESA at $40^{\circ} \mathrm{C}$.

\subsection{Wheel Tracking (WT)}

A WT test is considered one of the best tests to simulate field conditions. Thus, rutting behavior of compacted base mixes was simulated using a wheel track tester. Two slabs for each mix were compacted to their maximum dry density, which is the same density as in the dynamic triaxial test specimens, using dynamic compaction. From the marl, sabkha or sand mixed with FA, FSA, EA, and ESA, 24 slabs measuring $45 \mathrm{~cm} \times 22 \mathrm{~cm} \times 10 \mathrm{~cm}$ were prepared. The slabs were then cured at $40^{\circ} \mathrm{C}$ for 72 hours for foamed mixes and at $60^{\circ} \mathrm{C}$ for 48 hours for emulsified mixes and tested dry under a wheel load of $80 \mathrm{psi}(552 \mathrm{kPa})$ at $22^{\circ} \mathrm{C}$. Figure 21 shows samples of some tested slabs.

The results shown in Figs. 22-24 are the measured rut depths for the FA- and FSA-treated slabs of marl, sabkha, and sand soils, respectively. Results clearly show the same rankings as were obtained from the dynamic triaxial test; marl soil had the highest rutting resistance followed by sabkha and sand soil. Furthermore, the modified FSA mixes had less rutting susceptibility than the conventional foam mixes. Results also showed that the sand treated with FA or FSA is very sensitive to rutting and exhibited higher permanent deformation $(>15 \mathrm{~mm}$ within the first thousand load repetitions) compared to the other marl and sabkha mixes. The test section was considered failed when the vertical deformation was $\geq 25 \mathrm{~mm}$ ( 1 inch).

The results shown in Figs. 25-27 are the measured rut depths for EA and ESA mixes for marl, sabkha, and sand, respectively. Again, the same trend and ranking as in the dynamic triaxial was observed in which marl soil has the highest rutting resistance, followed by sabkha and sand soils. This means that rutting can be predicted from any of the test methods and compared reasonably well with other. Results also indicate that the ESA mixes showed lower rutting resistance than the emulsion mixes. In comparison to either normal or sulfur modified foam mixes, emulsified mixes are less resistant to permanent deformation than foamed mixes. This can be attributed to the fact that the FA treatment mechanism is different from that of the EA treatment. While EA tends to coat soil particles with a very fine asphalt layer, FA works more like a soil stabilized with lime whereas FA mostly binds the finer particles of the soil, improving its structure. As such, FSA has a stiff bond between fine soil particles of the mix (droplets constituted of FSA).

Results also showed that sand treated with EA or ESA is very sensitive to rutting and exhibited higher permanent deformation (>15 $\mathrm{mm}$ within the first thousand load repetitions) as compared to marl and sabkha mixes.

Generally, marl asphalt mixes are more resistant to permanent deformation than sand or sabkha mixes due to the higher internal friction angle of marl asphalt mixes, resulting in a longer secondary stage of permanent deformation. The low friction of dune and sabkha soils is attributed to the spherical nature of the particles.

In general, the relative performance ranking of accelerated pavement tests (APT) represented here by a loaded WT test and a dynamic triaxial repeated load test was found to be the same for all investigated mixes in this study. 


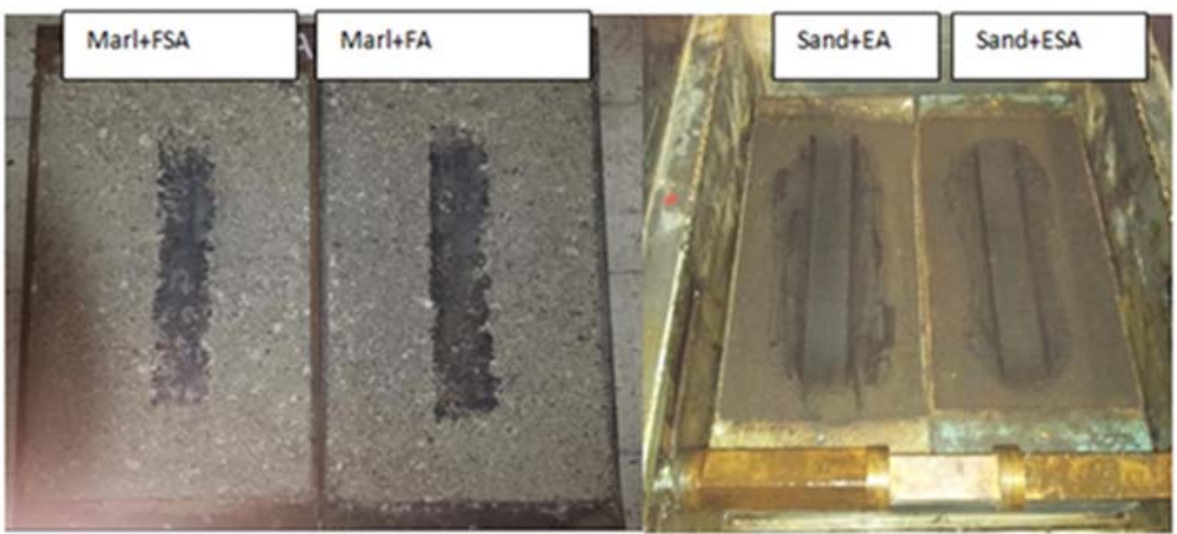

Figure 21. Permanent deformation in WT samples.

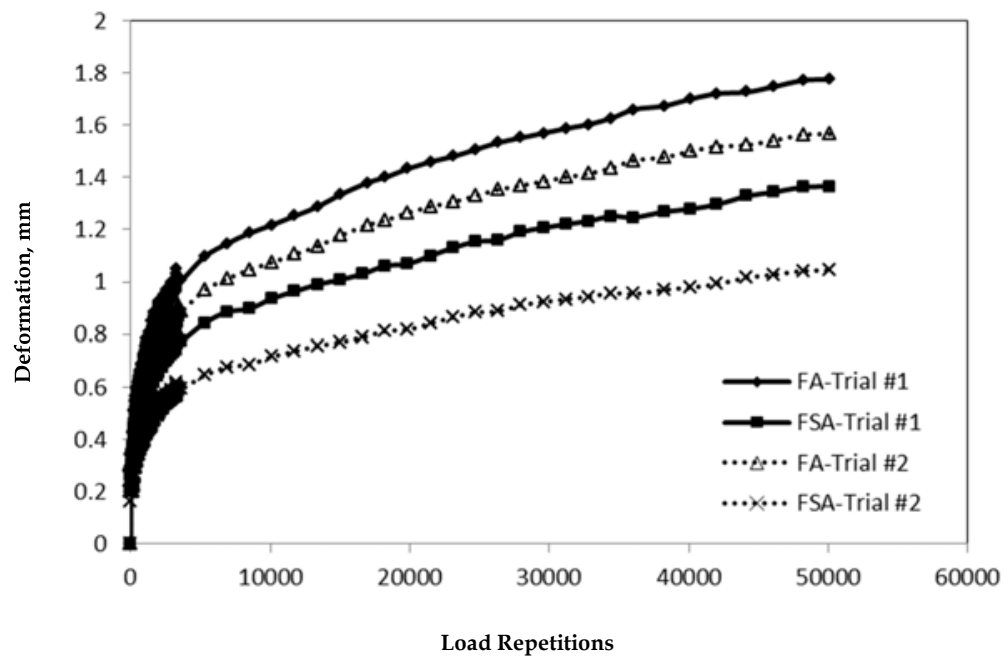

Figure 22. Results of the permanent deformation for the marl-FA/FSA mixes using a wheel track machine, dry at $22^{\circ} \mathrm{C}$.

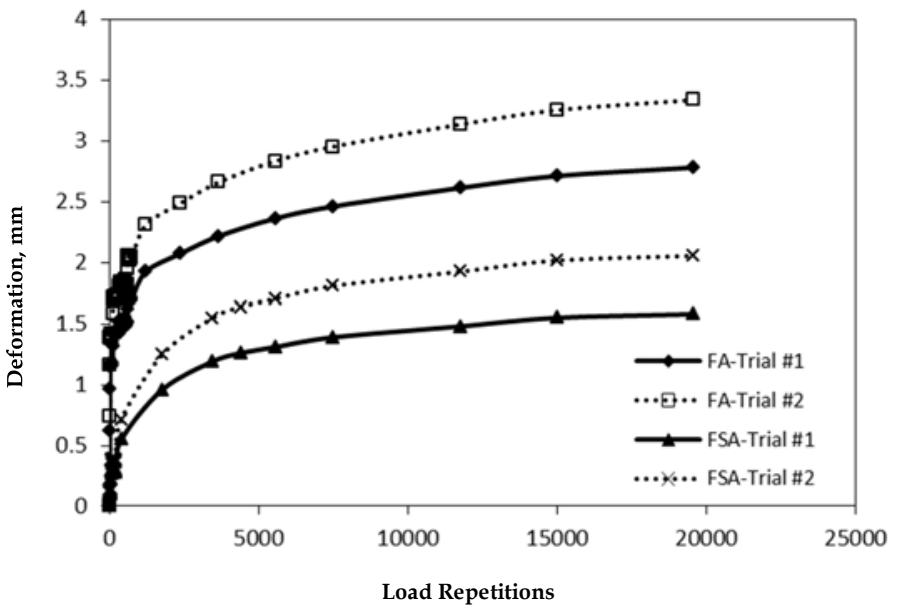

Figure 23. Results of the permanent deformation for the sabkha-FA/FSA mixes using wheel track machine, dry at $22^{\circ} \mathrm{C}$. 


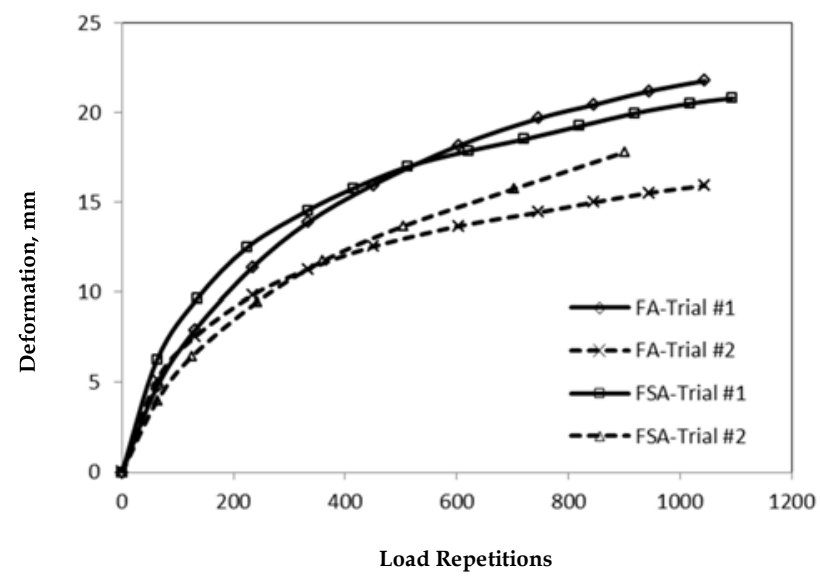

Figure 24. Results of the permanent deformation for the sand-FA/FSA mixes using a wheel track machine, dry at $22^{\circ} \mathrm{C}$.

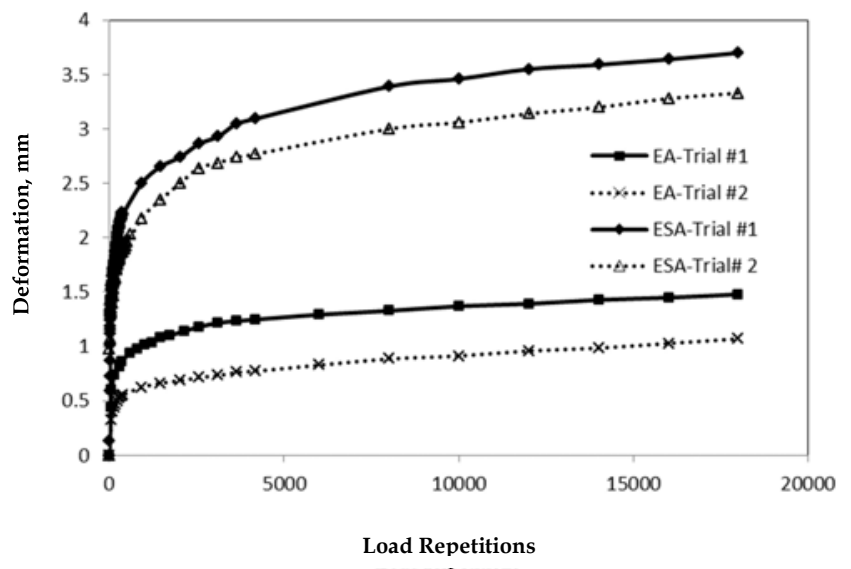

Figure 25. Results of the permanent deformation for the marl-EA/ESA mixes using a wheel track machine, dry at $22^{\circ} \mathrm{C}$.

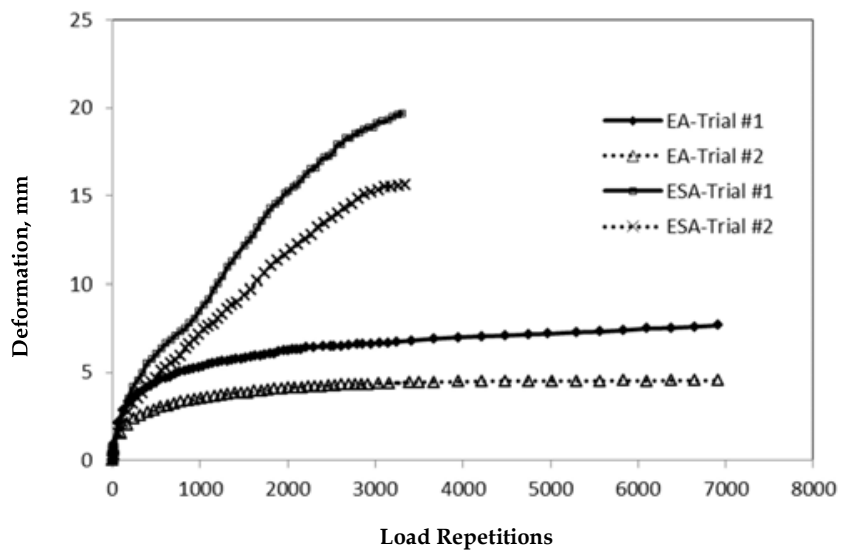

Figure 26. Results of the permanent deformation for the sabkha-EA/ESA mixes using wheel track machine, dry at $22^{\circ} \mathrm{C}$. 


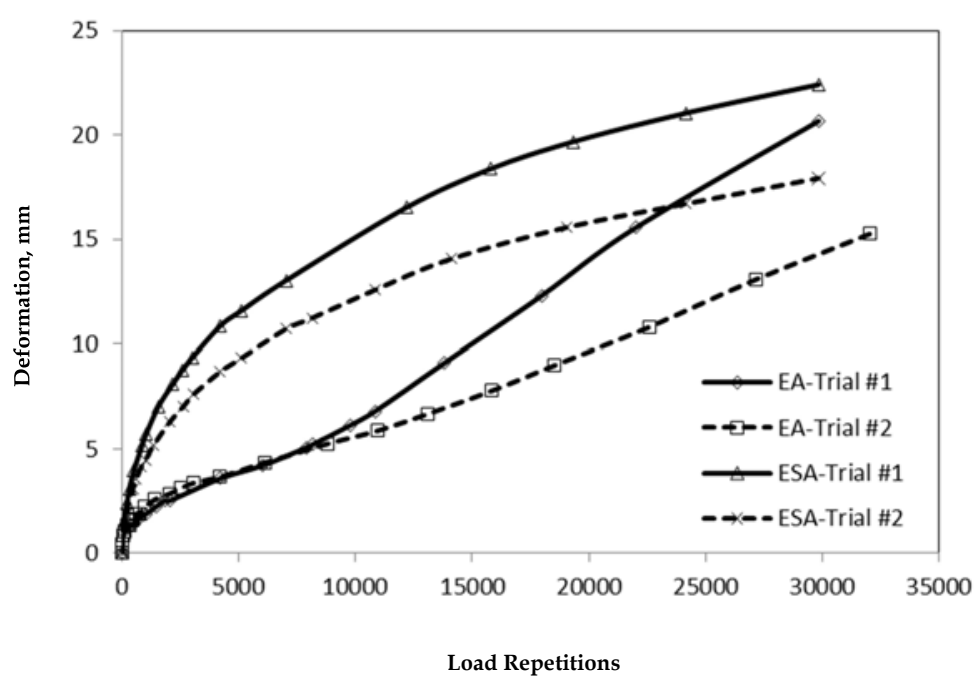

Figure 27. Results of the permanent deformation for the sand-EA/ESA mixes using wheel track machine, dry at $22^{\circ} \mathrm{C}$.

\section{Prediction of Permanent Deformation Using the VESYS Model}

The VESYS model includes two different flexible pavement rutting models: system and layer rutting. One advantage of the layer rutting model is its capability to predict both surface rutting and the permanent deformation in each layer of the pavement structure. The permanent deformation in each finite layer can be estimated as the product of the layer material permanent deformation law associated with that layer and the elastic compression at that layer which, in layer theory, is given by the difference in deflections of the top and bottom of the layer. Thus, the rut depth in any finite layer can be calculated from the following equation (Zhou and Scullion 2002):

$R_{D}(N)=\left(W^{+}-W^{-}\right)^{*} \frac{\mu_{i}}{1-\alpha_{i}} N\left(1-\alpha_{i}\right)$

where,

$\mathrm{R}_{\mathrm{D}}=$ the permanent deformation (rutting) level after $\mathrm{N}$ load repetitions;

$\mathrm{W}^{+}, \mathrm{W}^{-}=$the elastic deflection amplitudes of the top and bottom surfaces of the layer, respectively; $\mu_{\mathrm{i}}, \mathrm{a}_{\mathrm{i}}=$ the laboratory permanent deformation parameters for the each layer (i) material; $\mu=\frac{\mathrm{ab}}{\varpi_{\mathrm{r}}}, \quad a=1-b$

$\varepsilon_{\mathrm{r}}=\frac{\sigma_{\mathrm{d}}}{\mathrm{M}_{\mathrm{R}}}$

In this study, VESYS 5W software was used to analyze the pavement structure and conduct performance analysis. The two main input parameters in the VESYS $5 \mathrm{~W}$ rutting model are the permanent deformation parameters, $\alpha$ and $\mu$, for each layer.

To calculate the $M_{R}$ of the stabilized mixes, regression models with high coefficients of correlation in terms of deviator stress, confining pressure, and temperature were developed using Minitab software, Version 16 (Minitab, Inc., State College, Pennsylvania, USA) based on the results of the $M_{R}$ tests. Tables 2 and 3 present the $M_{R}$ models for FA and EA mixes, respectively.

The permanent deformation parameters ( $\alpha$ and $\mu$ ) for each mix were obtained by representing the accumulated permanent strain versus the number of load repetitions, represented as a curve resulting from the dynamic triaxial test on a log-log scale. The intercept and slope coefficients were determined and then $\alpha$ and $\mu$ were calculated according to Eqn. 6. Regression models were created using Minitab software, Version 16 to express these two parameters as functions of stress levels and temperature for foamed and emulsified mixes as shown in Tables 4 and Table 5, respectively. 
Table 2. Regression models of $\mathrm{M}_{\mathrm{R}}$ for FA mixes.

\begin{tabular}{cccc}
\hline $\begin{array}{c}\text { Material } \\
\text { Type }\end{array}$ & $\begin{array}{c}\text { Type of } \\
\text { Additive }\end{array}$ & $\mathbf{M}_{\mathbf{R}}$ & $\mathbf{R}^{2}$ \\
\hline \multirow{2}{*}{ Marl } & FA & $\mathrm{M}_{\mathrm{R}}=260-6.47 \mathrm{~T}+0.004 \sigma_{\mathrm{c}}+4.92 \sigma_{\mathrm{d}}$ & 0.989 \\
& FSA & $\mathrm{M}_{\mathrm{R}}=147-1.77 \mathrm{~T}-0.692 \sigma_{\mathrm{c}}+4.00 \sigma_{\mathrm{d}}$ & 0.982 \\
\multirow{3}{*}{ Sabkha } & FA & $\mathrm{M}_{\mathrm{R}}=256-6.16 \mathrm{~T}+0.079 \sigma_{\mathrm{c}}+4.51 \sigma_{\mathrm{d}}$ & 0.986 \\
& FSA & $\mathrm{M}_{\mathrm{R}}=115-1.53 \mathrm{~T}-0.393 \sigma_{\mathrm{c}}+3.82 \sigma_{\mathrm{d}}$ & 0.988 \\
\multirow{2}{*}{ Sand } & FA & $\mathrm{M}_{\mathrm{R}}=135-3.57 \mathrm{~T}+0.152 \sigma_{\mathrm{c}}+4.36 \sigma_{\mathrm{d}}$ & 0.977 \\
& FSA & $\mathrm{M}_{\mathrm{R}}=112-2.20 \mathrm{~T}-0.371 \sigma_{\mathrm{c}}+3.88 \sigma_{\mathrm{d}}$ & 0.991 \\
\hline \multicolumn{4}{c}{$\mathrm{M}_{\mathrm{R}}=$ resilient modulus; FA = foamed asphalt; FSA $=$ foamed sulfur asphalt. }
\end{tabular}

Table 3. Regression models of $\mathrm{M}_{\mathrm{R}}$ for EA mixes.

\begin{tabular}{cccc}
\hline $\begin{array}{c}\text { Material } \\
\text { Type }\end{array}$ & $\begin{array}{c}\text { Type of } \\
\text { Additive }\end{array}$ & \multicolumn{1}{c}{$\mathbf{M}_{\mathbf{R}}$} & $\mathbf{R}^{2}$ \\
\hline \multirow{2}{*}{ Marl } & EA & $\mathrm{M}_{\mathrm{R}}=128-2.26 \mathrm{~T}-0.513 \sigma_{\mathrm{c}}+4.52 \sigma_{\mathrm{d}}$ & 0.98 \\
& ESA & $\mathrm{M}_{\mathrm{R}}=119-2.49 \mathrm{~T}-0.257 \sigma_{\mathrm{c}}+4.61 \sigma_{\mathrm{d}}$ & 0.993 \\
Sabkha & EA & $\mathrm{M}_{\mathrm{R}}=158-3.07 \mathrm{~T}-0.346 \sigma_{\mathrm{c}}+4.05 \sigma_{\mathrm{d}}$ & 0.988 \\
& ESA & $\mathrm{M}_{\mathrm{R}}=139-2.39 \mathrm{~T}-0.417 \sigma_{\mathrm{c}}+4.25 \sigma_{\mathrm{d}}$ & 0.99 \\
Sand & EA & $\mathrm{M}_{\mathrm{R}}=151-3.21 \mathrm{~T}-0.093 \sigma_{\mathrm{c}}+3.79 \sigma_{\mathrm{d}}$ & 0.99 \\
& ESA & $\mathrm{M}_{\mathrm{R}}=86.1-1.05 \mathrm{~T}-0.329 \sigma_{\mathrm{c}}+4.01 \sigma_{\mathrm{d}}$ & 0.992 \\
\hline
\end{tabular}

$\mathrm{M}_{\mathrm{R}}=$ resilient modulus; $\mathrm{EA}=$ emulsified asphalt; $\mathrm{ESA}=$ emulsified sulfur asphalt.

Table 4. Regression models of $\mu$ and a for FA mixes.

\begin{tabular}{cccccc}
\hline $\begin{array}{c}\text { Soil } \\
\text { Type }\end{array}$ & $\begin{array}{c}\text { Stab- } \\
\text { ilizer }\end{array}$ & $\boldsymbol{\mu}$ & $\mathbf{R}^{2}$ & $\mathbf{\alpha}$ & $\mathbf{R}^{2}$ \\
\hline \multirow{2}{*}{ Marl } & FA & $\mu=-5.81+0.0161 \mathrm{~T}+0.0133 \sigma_{\mathrm{d}}$ & 0.97 & $\alpha=1.15+0.000037 \mathrm{~T}-0.000598 \sigma_{\mathrm{d}}$ & 0.95 \\
& FSA & $\mu=-1.53+0.0189 \mathrm{~T}+0.00325 \sigma_{\mathrm{d}}$ & 0.934 & $\alpha=1.04-0.00115 \mathrm{~T}-0.000334 \sigma_{\mathrm{d}}$ & 0.974 \\
& FA & $\mu=-3.80+0.0502 \mathrm{~T}+0.0125 \sigma_{\mathrm{d}}$ & 0.95 & $\alpha=0.805+0.000926 \mathrm{~T}-0.000181 \sigma_{\mathrm{d}}$ & 0.962 \\
Sabkha & FSA & $\mu=-1.88+0.0204 \mathrm{~T}+0.00776 \sigma_{\mathrm{d}}$ & 0.882 & $\alpha=0.865-0.000741 \mathrm{~T}-0.000181 \sigma_{\mathrm{d}}$ & 0.892 \\
& FA & $\mu=-14.7+0.345 \mathrm{~T}+0.0261 \sigma_{\mathrm{d}}$ & 0.85 & $\alpha=1.93-0.0247 \mathrm{~T}-0.00154 \sigma_{\mathrm{d}}$ & 0.902 \\
Sand & FSA & $\mu=-15.1+0.232 \mathrm{~T}+0.0346 \sigma_{\mathrm{d}}$ & 0.678 & $\alpha=1.37-0.00148 \mathrm{~T}-0.00149 \sigma_{\mathrm{d}}$ & 0.505 \\
\hline \multicolumn{7}{c}{ FA = foamed asphalt; FSA = foamed sulfur asphalt. }
\end{tabular}


Table 5. Regression models of $\mu$ and a for EA mixes.

\begin{tabular}{cccccc}
\hline $\begin{array}{c}\text { Soil } \\
\text { Type }\end{array}$ & $\begin{array}{c}\text { Stab- } \\
\text { ilizer }\end{array}$ & $\boldsymbol{\mu}$ & $\mathbf{R}^{2}$ & $\mathbf{\alpha}$ & $\mathbf{R}^{2}$ \\
\hline \multirow{2}{*}{ Marl } & EA & $\mu=-0.113-0.00005 \mathrm{~T}+0.00113 \sigma_{\mathrm{d}}$ & 0.914 & $\mathrm{a}=0.812+0.00326 \mathrm{~T}+0.00004 \sigma_{\mathrm{d}}$ & 0.949 \\
& ESA & $\mu=-10.9+0.037 \mathrm{~T}+0.0278 \sigma_{\mathrm{d}}$ & 0.826 & $\mathrm{a}=1.14-0.000296 \mathrm{~T}-0.000518 \sigma_{\mathrm{d}}$ & 0.916 \\
& EA & $\mu=-3.31+0.0247 \mathrm{~T}+0.0137 \sigma_{\mathrm{d}}$ & 0.867 & $\mathrm{a}=1.17-0.00444 \mathrm{~T}-0.000979 \sigma_{\mathrm{d}}$ & 0.715 \\
Sabkha & ESA & $\mu=-0.91-0.0719 \mathrm{~T}+0.0157 \sigma_{\mathrm{d}}$ & 0.811 & $\mathrm{a}=0.341+0.0146 \mathrm{~T}+0.000036 \sigma_{\mathrm{d}}$ & 0.915 \\
& EA & $\mu=-5.63+0.107 \mathrm{~T}+0.00897 \sigma_{\mathrm{d}}$ & 0.714 & $\mathrm{a}=2.17-0.0280 \mathrm{~T}-0.00178 \sigma_{\mathrm{d}}$ & 0.918 \\
Sand & ESA & $\mu=-2.51-0.0454 \mathrm{~T}+0.0124 \sigma_{\mathrm{d}}$ & 0.706 & $\mathrm{a}=0.735+0.0181 \mathrm{~T}-0.00123 \sigma_{\mathrm{d}}$ & 0.895 \\
\hline
\end{tabular}

EA $=$ emulsified asphalt; ESA $=$ emulsified sulfur asphalt.

Table 6. Calibration factors for $\alpha$ and $\mu$.

\begin{tabular}{ccll}
\hline $\begin{array}{l}\text { Soil } \\
\text { Type }\end{array}$ & Treatment Type & $\mathbf{\alpha}_{\mathrm{CF}}$ & $\boldsymbol{\mu}_{\mathrm{CF}}$ \\
\hline Marl & FA & 0.8904 & 1.058 \\
& FSA & 0.9638 & 2.50 \\
Sabkha & FA & 1.0959 & 1.429 \\
& FSA & 0.8267 & 0.351 \\
Sand & FA & 0.6604 & 1.16 \\
& FSA & 0.7843 & 1.098 \\
Marl & EA & 0.7912 & 2.941 \\
& ESA & 0.9412 & 1.331 \\
Sabkha & EA & 1.321 & 1.77 \\
Sand & ESA & 0.60 & 0.903 \\
FSA $=$ foamed sulfur asphalt; EA $=$ emulsified asphalt; ESA $=$ emulsified sulfur asphalt.
\end{tabular}

where,

$\mu$ and $\alpha=$ permanent deformation properties of the materials;

$\mathrm{T}=$ temperature in degree

$\sigma_{\mathrm{d}}=$ deviator stress in $\mathrm{kPa}$

\subsection{Validation and Calibration of Rut Depth Prediction Models}

Simulation in accelerated pavement tests (APT), such as through a WT test, is the most effective manner to simulate the impact of traffic loading and environmental conditions on pavement configurations. These tests are also known as the Hamburg WT and used for the Superpave evaluation process. The rutting prediction models derived in this study are based on the dynamic triaxial test, which is different from wheel tracking (WT) in many respects such as boundary conditions and traffic loading. However, both methods remain only a simulation of actual behavior of the material (Jawad et al. 2013). It is necessary to verify and calibrate these models with the results of the WT test, which presents a better simulation of actual field conditions.

Figure 28 shows the procedure of the calibration process. First, the permanent deformation properties of the materials ( $\alpha$ and $\mu$ ) were calculated from the developed triaxial models at a temperature of $22^{\circ} \mathrm{C}$ and under a deviator stress of $552 \mathrm{kPa}$ (similar to a WT test) for each mix. Data were entered into VESYS $5 \mathrm{~W}$ software and rut depths were predicted. The predicted rut depths were compared with the rut depths measured using the WT tests. If the predicted rut depth was similar to the measured rut depth (within $90 \%$ of the calculated value), then it was determined that 
there was no need for calibration and the model could be used for rutting prediction. Otherwise, $\alpha$ and $\mu$ were multiplied by the ratio of the recent predicted rut depth $\left(\mathrm{R}_{\mathrm{D}+1}\right)$ to the rut depth predicted in the previous step $\left(\mathrm{R}_{\mathrm{D}}\right)$ and called $\alpha_{i+1}$ and $\mu_{i+1}$ as shown in the flowchart. $\alpha_{i+1}$ and $\mu_{i+1}$ were re-entered into the VESYS $5 \mathrm{~W}$ software and the process was repeated until the predicted rut depth was within $90 \%$ of the WT-measured rut depth. Finally, calibration factors for the permanent deformation properties ( $\alpha$ and $\mu$ ) for each mix were determined (Table 6 ). It is worth mentioning that these factors were used only for the marginal soils (marl, sabkha, and dune sand) whose basic properties and classifications are listed in this paper.

Figures 29 and 30 show the WT-measured and VESYS 5W-predicted rut depth curves for the marl treated with FSA and ESA, respectively, as an example of the rutting prediction using calibrated models. It is clear from the figures that the calibrated models have predicted the rutting values close to that measured using a WT test.

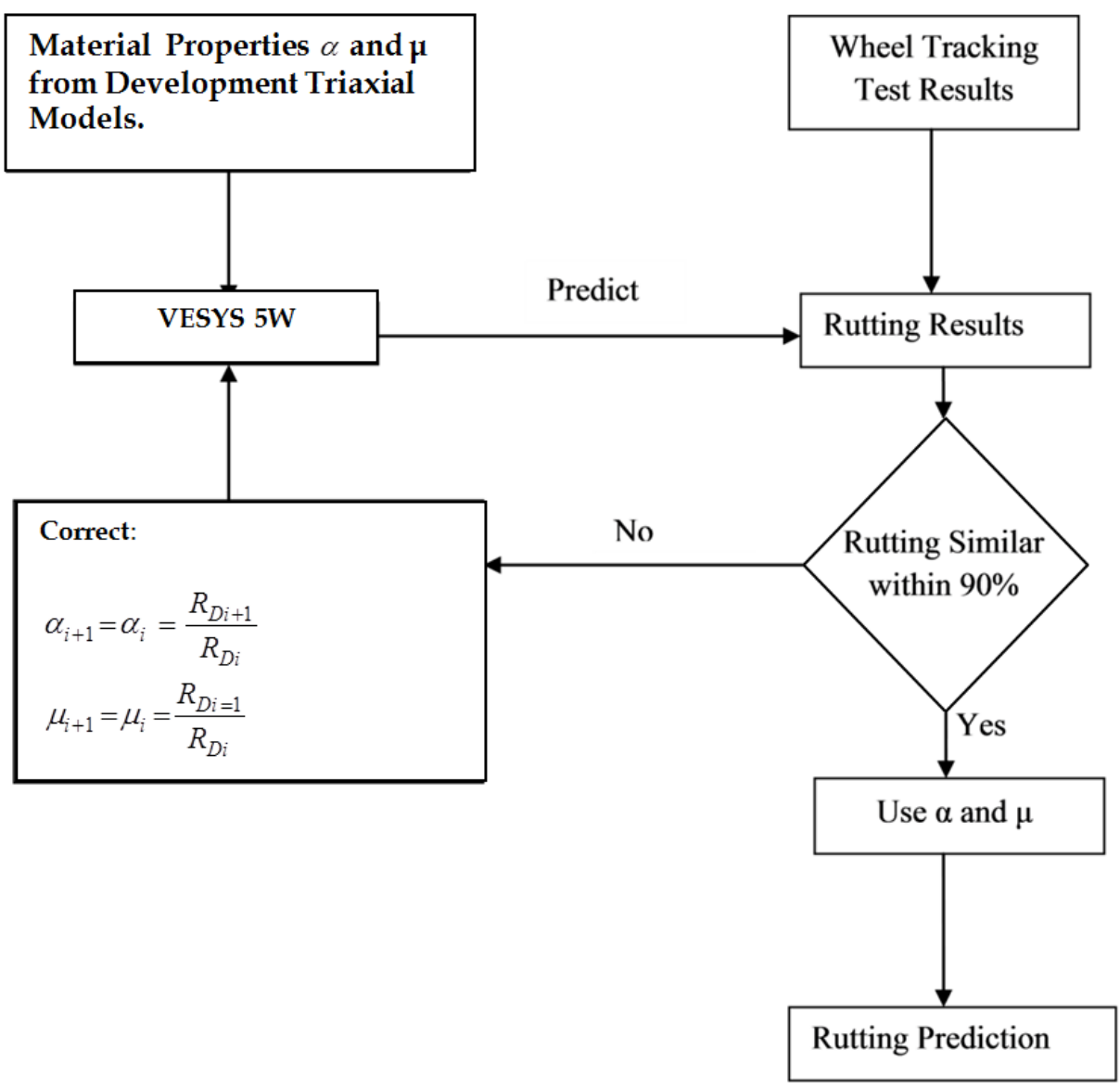

Figure 28. Model calibration flowchart. 


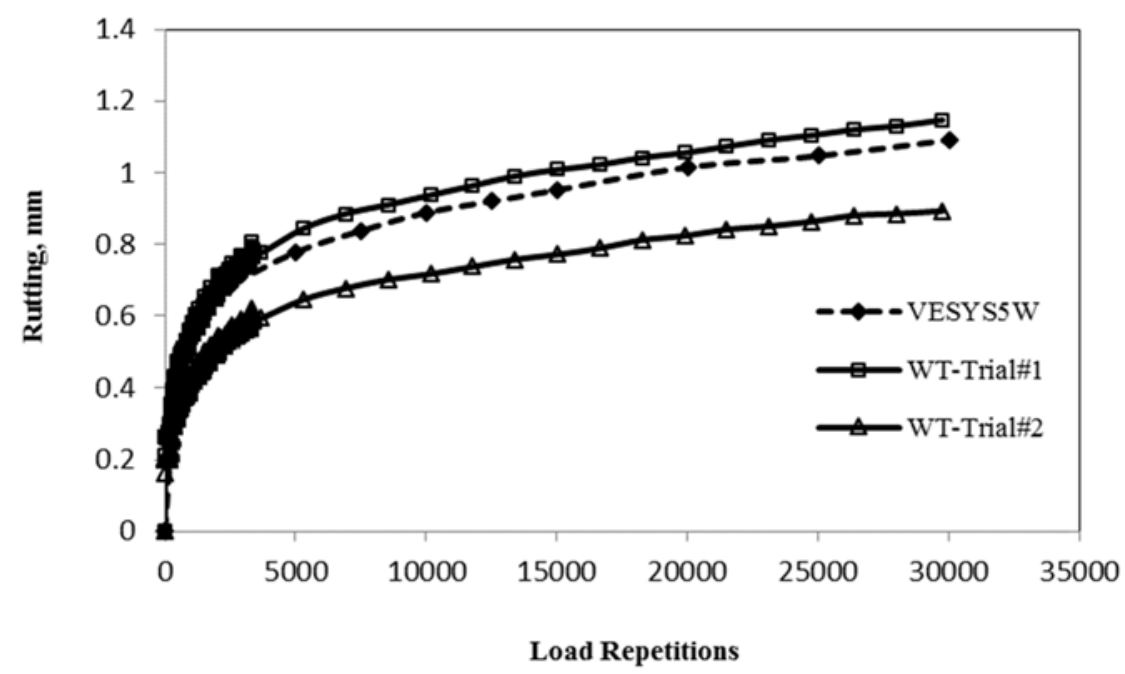

Figure 29. Measured and predicted for marl-FSA mixes.

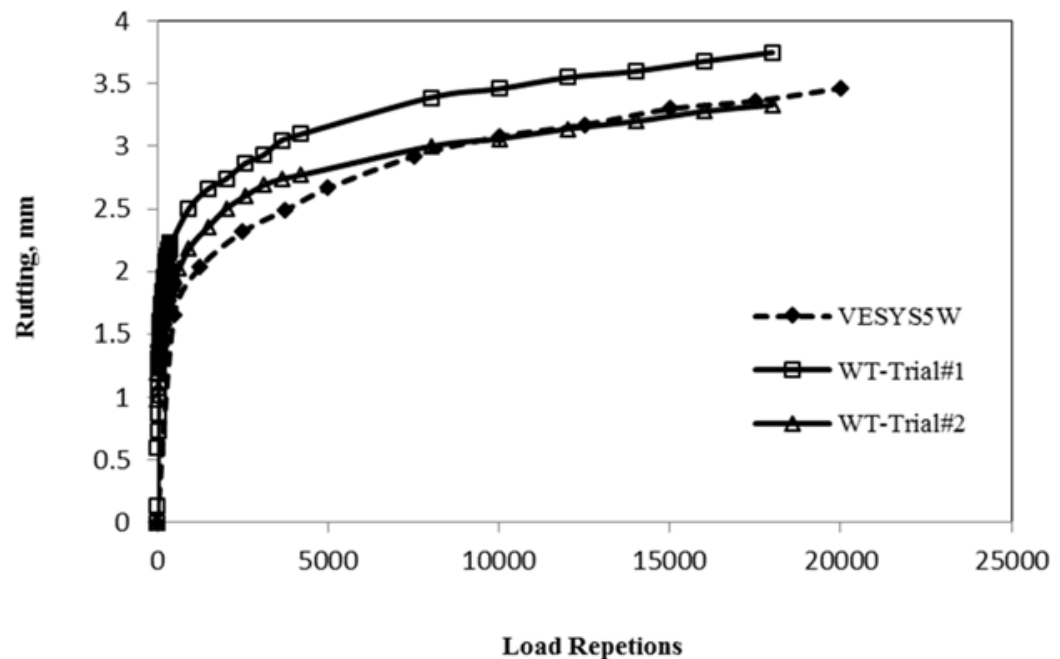

Figure 30. Measured and predicted for marl-ESA mixes.

\section{Conclusion}

This paper summarizes a laboratory investigation to evaluate the permanent deformation of marl, sabkha and dune sand soils treated with FSA and ESA as well as conventional FA and EA by conducting dynamic triaxial and WT tests and developed and calibrated models for rutting prediction. Based on the results of this study, the following conclusions are drawn:

1. The $M_{R}$ of FSA mixes are slightly less than those of FA mixes. However, the $M_{R}$ of ESA mixes are slightly higher than EA mixes.
2. FSA mixes showed superior rutting resistance compared with FA mixes and less temperature susceptibility.

3. ESA was found to increase the permanent deformation susceptibility of soil mixes.

4. Permanent deformation prediction models for the investigated mixes were developed and calibrated with the WT test results, and the calibrated models were found to predict the rut depth with $90 \%$ accuracy.

5. The VESYS 5W program is suitable to predict rut depth since it can predict the layer rut depth and the total rut depth of the pavement structure with a $90 \%$ degree of accuracy. 


\section{Acknowledgment}

The authors would like to acknowledge the support provided by King Fahd University of Petroleum and Minerals (KFUPM) for the execution of this research.

\section{References}

Abdullah and Wahhab, Gamil MSA, Hamad I. AlAbdul W (2015), Evaluation of foamed sulfur asphalt stabilized soils for road applications. Construction and Building Materials 88: 149-158.

Abdullah, Gamil MSA (2014), Modeling the behavior of sulfur modified foamed and emulsified asphalt soils mixes for local road applications. Ph.D Dissertation, King Fahd University of Petroleum and Minerals, Dhahran, Saudi Arabia.

Asphalt Emulsion Manufacturers Association (AEMA) (2004), A basic asphalt emulsion manual. Manual Series (MS) No. 19.

Asphalt Institute (1996), Superpave TM mix design. Superpave Series SP-2, Lexington, Kentucky, USA.

Barenberg, Ernest JB, Marshall RT (1990), Calibrated mechanistic structural analysis procedures for pavements phase 1 \& II of NCHRP project 1-26. National Cooperative Highway Research Program". Transportation Research Board. Washington, DC.

Bevan WS (2002), Development of flow number and flow time candidate simple performance test for asphalt mixtures. MS Thesis. Department of Civil and Environmental Engineering, Arizona State University.

Diyaljee, Vishnu AD, Gerald PR (1982), Repetitive load deformation of cohesionless soil. Journal of the Geotechnical Engineering Division. Proc. ASCE 108(10): 1215-1229.

Garba, Rabbira G (2002), Permanent deformation properties of asphalt concrete mixtures. PhD
Thesis, Norwegian University of Science and Technology.

Gholam AB, William OY (1996), Determination of elastic and plastic subgrade soil parameters for asphalt cracking and rutting prediction. Transp. Res. Rec. 1540, Transportation Research Board, Washington DC. 97-104.

Hafeez, Imran H (2009), Impact of hot mix asphalt properties on its permanent deformation behavior. 05- UET/ PhD-CE-22, University of Engineering and Technology, TAXILA.

Jawad H, Douglas JW, Theunis FPH, David A (2013), Comparing results between the repeated load triaxial test rand accelerated pavement test on unbound aggregate. Journal of Materials in Civil Engineering 26(3): 476-483.

Khedr, Safwan AK (1986), Deformation mechanism in asphaltic concrete. Journal of Transportation Engineering ASCE112(1): 29-45.

Li, Liu, Peng L, Juanyu L (2010), Characterization of asphalt treated base course material. (No. FHWA-AK-RD-10-07). Alaska University Transport Centre. Alaska, USA.

Monismith, Carl LM (1976), Rutting prediction in asphalt concrete pavements. Transp. Res. Rec. 616, Transportation Research Board, Washington, D.C. 2-8.

Vuong B, Peter A (1991), Repeated load triaxial testing on the subgrade from mulgrace ALF site. Australian Road Research Board, WD RI91/023.

Wahhab, Hamad IA, Mirza MB, Isam MA, Hisham MK (2012), Study of road bases construction in Saudi Arabia using foam asphalt. Construction and Building Materials 26: 113-121.

Zhu and Scullion, Fujie Z, Thomas S (2002), VESYS5 rutting model calibrations with local accelerated pavement test data and associated implementation. Report No. FHWA/TX-03/91502-01-2, Texas Transportation Institute, College Station, TX. 